ANUARIo DE Estudios Medievales (AEM)

37/1, enero-junio de 2007

pp. $27-69$

ISSN 0066-5061

\title{
POR LA QUOAL COSA ES DAPNADO. SUICIDIO Y MUERTE ACCIDENTAL EN LA NAVARRA BAJOMEDIEVAL
}

\author{
"POR LA QUOAL COSA ES DAPNADO". \\ SUICIDE AND ACCIDENTAL DEATH \\ IN LATE MEDIEVAL NAVARRE
}

Resumen: El suicidio fue considerado a lo largo de la Edad Media como un homicidio debido a que incurría en el más grave de los pecados: la privación de la propia vida creada por Dios. Por ello estaba sujeto a una serie de castigos inflingidos por su misma comunidad de vecinos así como a penalizaciones legales, entre las que destacaban el embargo de sus bienes, la prohibición de cristiana sepultura y el ajusticiamiento del cadáver. Sin embargo, existieron algunos atenuantes, como la locura, que beneficiaron a los suicidas y minimizaron las penas aplicadas. No obstante, la doctrina eclesiástica, a diferencia del planteamiento de las autoridades civiles, manifestó el afán y la necesidad de evitar los castigos infamantes y optó por la prevención a través de la vía catequética y el perdón de los supervivientes. En Navarra, las actuaciones legales se centraron en el marco civil, por ser el suicidio una traición directa al rey y a la Corona, mientras que la jerarquía religiosa se mantuvo al margen de estos asuntos.

Palabras clave: Suicidio; Muerte accidental; Castigos; Sanciones; Legislación civil; Legislación eclesiástica; Edad Media; Navarra.
JULIA BALDÓ ALCOZ Universidad de Navarra, Pamplona

A Miguel Ángel Galdeano. In memoriam

Abstract: Suicide was considered all along the Middle Ages an homicide, because the destruction of the sacred present of life and, therefore, the most offensive sin against God, creator of life. Consequently, suicides were subjected to the scorn of the community and suicide brought legal actions, with penalizations such as the confiscation of suicide's properties and the humbling of their soul and body, hanging and mutilating the corpses and denniying ecclesiastical sepulture. Anyway, suicides commited under madness were not prosecuted. Official theories and regulations of the civil and ecclesiastical authorities were radically different because Church officials preferred to apply prevention methods as cathequesis and forgave and absolve the survivors. In Navarre the legal punishments were employed only by civil authorities because suicide was an act of felony, an offence against the Crown, and Church obeyed the King's rules.

Keywords: Suicide; Accidental Death; Punishments; Sentences; Civil Laws; Ecclesiastical Laws; Middle Ages; Navarre. 


\section{SUMARIO}

1. Incidencia en la historiografía de la muerte.- 2. Incidencia en la documentación, tipología documental.- 3. Concepto de suicidio.- 4. Dimensión del suicidio y de la muerte accidental. 5. Consecuencias jurídicas y sociales del suicidio.

El suicidio durante toda la Edad Media, a diferencia de lo que sucedió durante épocas pretéritas, fue considerado como una de las más temibles formas de fallecimiento y el pecado más grave que se podía cometer contra Dios debido a que suponía el aborrecimiento de la propia vida, un don al que sólo podía dar término el Creador. Por ello y porque este acto implicaba y conllevaba la suma de todos los miedos, rechazos y pecados de la comunidad medieval, fue englobado en la categoría de "mala muerte", como se verá a lo largo de este estudio.

Este asunto, a diferencia de otros aspectos vinculados a la muerte, ha sido muy poco estudiado en el ámbito hispánico, por lo que la mayor parte de las referencias bibliográficas que se han utilizado en este trabajo han sido fundamentalmente análisis efectuados para otras regiones europeas.

Atendiendo a estos precedentes, la incursión en este tema fue determinada por dos hechos cruciales. El primero de ellos radicó en una serie de labores de investigación documental, que permitieron el hallazgo de diferentes referencias al suicidio entre diversos textos encuadrados en la Sección de Comptos del Archivo General de Navarra.

El segundo de ellos fue el conocimiento de la obra de Ariel Guiance ${ }^{1}$ y la asistencia a una conferencia que pronunció en la Universidad de Navarra sobre este mismo tema, que vinieron a confirmar la enorme importancia de estas noticias y la excepcionalidad de estos testimonios dentro del ámbito hispánico. Como consecuencia de todo ello, se emprendió una investigación que formó parte de la tesis doctoral "Requiem aeternam. Ritos, actitudes y espacios en torno a la muerte en la Navarra bajomedieval", dirigida por la doctora Julia Pavón Benito ${ }^{2}$. Así fue como, en vista del interés suscitado y por consejo de los miembros del tribunal que juzgó dicha tesis, se ha decidido publicar este apartado como un estudio monográfico independiente ${ }^{3}$.

Los análisis y estudios documentales que se efectuaron permitieron la recopilación de 53 referencias datadas entre finales del siglo XIII y las

\footnotetext{
${ }^{1}$ Ariel GUIANCE, Los discursos sobre la muerte en la Castilla medieval (siglos VII-XV), Valladolid, 1998.

${ }^{2}$ Esta publicación que aquí se presenta ha formado parte de uno de los capítulos de la tesis doctoral Requiem aeternam. Ritos, actitudes y espacios en torno a la muerte en la Navarra bajomedieval. Universidad de Navarra, Pamplona, 2005 que fue financiada por la Fundación Caja Madrid (año 2000) y el Gobierno de Navarra (2001-2004) - Este estudio estuvo integrado en el Proyecto de Investigación Interdisciplinar "La muerte en la Navarra medieval" (1998-2003) dirigido por la doctora Julia Pavón Benito y compuesto por Ildefonso Adeva Martín, Javier Martínez de Aguirre Aldaz, Mikel Ramos Aguirre, Angeles García de la Borbolla García de Paredes y Julia Baldó Alcoz. Dichọ proyecto recibió el respaldo económico de la Universidad de Navarra, el Ministerio de Ciencia y Tecnología (PB 1998-0220), el Gobierno de Navarra (Resolución 96/2000, de 15 de Diciembre) y la fundación privada The Friendly Hand.

${ }^{3}$ Los miembros integrantes del mencionado tribunal fueron los doctores Martín Aurell, Flocel Sabaté, Cécile Treffort, Carmina García Herrero y Angeles García de la Borbolla.
} 
postrimerías del XV conservadas en la sección de Comptos del Archivo General de Navarra ${ }^{4}$. De ellas, 42 corresponderían a suicidios probados 5 , 4 a muertes accidentales demostradas, 6 a muertes sospechosas que podrían ser englobadas como muertes accidentales, en unos casos, y como posibles suicidios, en otros, y 1 a una tentativa de suicidio. A partir de los datos obtenidos se establecieron una serie de porcentajes y conclusiones que deben ser tomados como referencias orientativas para explicar determinadas actuaciones, sin que por ello puedan ser extrapoladas fuera de este contexto - geográfico y cronológico - ni impuestas como una actitud generalizada de lo que ocurría en los restantes territorios hispánicos coetáneos.

Así pues, se ha procedido a presentar una visión general del suicidio haciendo hincapié en la fase bajomedieval, pero sin olvidar los antecedentes de etapas anteriores que permiten comprender la evolución de esta práctica a lo largo de los siglos y su impacto en la sociedad de la época. Para ello, se ha constituido un marco comparativo con otras regiones del Occidente medieval que permite ilustrar sus similitudes y diferencias con los usos navarros. Para ello y en primer lugar, se han analizado las circunstancias que rodean al acto suicida (fecha, hora, modo de llevarlo a cabo) así como la proyección del mismo en los diferentes grupos sociales. Posteriormente se ha examinado el tratamiento judicial del acto homicida así como las consecuencias jurídicas del mismo tanto en la propia víctima como en su entorno cercano (ajusticiamiento del cuerpo, privación de funerales y sepultura cristianos y confiscación de propiedades) y los atenuantes aplicados en función de las motivaciones del suicida para atentar contra su vida (locura, melancolía). E igualmente se han tenido en cuenta otros asuntos como las muertes accidentales o las tentativas de suicidio, con la intención de arrojar luz sobre un asunto escabroso que conlleva, en sí mismo, una connotación extremadamente negativa a ojos profanos y que viene determinada por un desconocimiento de todas las causas $\mathrm{y}$ circunstancias históricas y mentales que convergen en torno a esta controvertida cuestión.

\section{INCIDENCIA EN LA HISTORIOGRAFÍA DE LA MUERTE}

Señalaba Georges Minois que, en los grandes estudios sobre la muerte llevados a cabo durante las décadas de 1970 y 1980, autores sumamente

${ }^{4}$ José Ramón CASTRO y Florencio IDOATE, Archivo General de Navarra. Catálogo de la Sección de Comptos. Documentos. José Ramón CASTRO, vols. I a XXXVI y Fiorencio IDOATE, vols. XXXVII a L, Pamplona, 1952-1970. Florencio IDOATE, Archivo General de Navarra. Catálogo de la Sección de Comptos. Registros, vols. LI y LII, Pamplona, 1974. Y José Ramón CASTRO, Florencio IDOATE, Javier BALEZTENA, Catálogo del Archivo General de Navarra. Sección de Comptos. Documentos. Adiciones I (Años 1092-1400) y Adiciones II (Años 1401 1588), Pamplona, 1988 y 1993.

${ }^{5}$ En total se han recopilado 42 referencias que aluden a 33 individuos. A estos datos puede añadirse otra noticia más de este cariz contenida en Florencio IDOATE, Un registro de canclllería del siglo XIV. El cartulario de don Carlos II el Malo "Príncipe de Viana", LXX-LXXI, LXXIILXIIP (1958), pp. 179-228, 337-357, doc. núm. 562 . 
conocidos como Michel Vovelle, François Lebrun, Pierre Chaunu o Philippe Ariès no se detuvieron en la cuestión del suicidio ${ }^{6}$. Todo ello pudo ser debido a que este asunto fue considerado un tabú a lo largo de los siglos, y a que las fuentes que lo documentaban -escasas, muy dispersas y, en muchas ocasiones, ajenas a un patrón común- no se prestaban a un análisis cuantitativo atractivo para los investigadores ${ }^{7}$.

El primero que se interesó de forma histórica por esta temática fue Jean-Claude Schmitt (1976) mediante la publicación de una síntesis sobre el suicidio en la Edad Media ${ }^{8}$. Le siguió Georges Minois con una monografía que, con todo, no se centraba exclusivamente en el período medieval, sino que lo rebasaba ampliamente hasta llegar al siglo XX. Pero ha sido Alexander Murray el que ha realizado la más amplia investigación sobre este asunto, enmarcada exclusivamente en el medievo ${ }^{9}$. Dicho trabajo, que promete ser el más exhaustivo llevado a cabo hasta el momento ${ }^{10}$, abarca fuentes documentales de un amplio marco geográfico (Inglaterra, Francia, Alemania e Italia), permitiendo comprobar las similitudes y diferencias en torno a este espinoso tema a lo ancho de la Europa medieval, y convirtiéndose en punto de partida y modelo para otras investigaciones historiográficas.

Debe añadirse, en última instancia, que en España esta cuestión tampoco ha sido cultivada por los investigadores de la muerte, pudiendo quedar disculpados por la escasez de fuentes que aportan datos al respecto. No obstante, existen excepciones, como la de Ariel Guiance, quien realizó una original y excelente investigación sobre la mentalidad ante la muerte en Castilla para las centurias alto y bajomedievales. Este autor dedicó un capítulo de su monografía al estudio del suicida, el acto del suicidio y las causas del mismo y además se detuvo en el tratamiento que recibió por parte de las autoridades y de la sociedad ${ }^{11}$. Y, más recientemente, Laura Vivanco, que ha tratado este tema centrándolo igualmente en el ámbito castellano aunque en esta ocasión para la centuria del XV. Esta autora ha dividido su investigación

${ }^{6}$ Georges MiNoIs, History of Suicide. Voluntary Death in Western Cultures, Baltimore (EE. UU.), 1999 , p. 1. (trad. de orig. Histoire du suicide: La société occidentale face à la mort volontaire, París, 1995).

${ }^{7}$ Georges MINOIS, L'historien et la question du suicide "L'histoire (Dossier: Le suicide en Occident: de l'éloge a la condamnation)", 189 (1995), p. 24.

${ }^{8}$ Jean-Claude SchmitT, Le suicide, au Moyen Âge, “Annales E.S.C.”, XXXIV, 1 (1976), pp. 3-28. Anteriormente, autores como Emile Durkheim (Suicide, 1897) habían tratado el asunto desde el punto de vista de la sociología, la psiquiatría o del psicoanálisis. Albert BAYET (Le suicide et la morale, 1922), fue el precursor del estudio del tema desde una posición histórica, aunque desde una perspectiva moral.

${ }^{9}$ Alexander MURRAY, La grande mélancolie du Moyen Âge, "L'histoire", 189 (1995), pp. 3435. Idem, Suicide in the Midale Ages. Volume I: The Violent against Themselves, Oxxord-Nueva Nueva York, 2000. Idem, Suicide in the Middle Ages. Volume III: The Mapping of Mental Desolation, Öxford-Nueva York, (en prensa).

${ }^{10}$ Destaca también para Francia y el ámbito monástico la investigación realizada por Penelope JOHNSON Suicide and its Prevention in Later Medieval France, "The Proceedings of the Western Society for French Studies", 26 (2000), pp. 184-191.

${ }^{11} \mathrm{~A}$. GuIANCE, Los discursos sobre la muerte en la Castilla medieval, pp. 360-379. Y Morir por la patria, morir por la fe: la ideología de la muerte en la "Historia de rebus Hispaniae", "Cuadernos de Historia de España", 73 (1991), pp. 75-106. 
en una serie de categorías como muertes "repentinas", muertes derivadas de procesos jurídicos por actos delictivos-criminales y muertes "autoinfligidas", que quedarían encuadradas en el margo de "mala muerte" ${ }^{12}$. Asimismo, en Navarra se cuenta con alguna breve aportación en la obra de Fernando Videgáin que más bien se orienta hacia una vertiente documental en el marco cronológico en la Edad Moderna ${ }^{13}$.

\section{INCIDENCIA EN LA DOCUMENTACIÓN, TIPOLOGÍA DOCUMENTAL}

Las noticias relativas a suicidios que han podido recogerse para la Navarra medieval se han hallado preferentemente en dos tipos de fuentes documentales. En primer lugar, en la legislación, específicamente en el Fuero General de Navarra y en los fueros locales. En segundo lugar, en textos de tipo hacendístico-administrativo. Si bien los primeros aportan referencias sobre el marco jurídico en que se desenvuelve la población, son los segundos los que ofrecen datos más interesantes permitiendo conocer la aplicación de estas normativas así como las posibles alteraciones introducidas para casos inusuales. De este modo, estos últimos - que se corresponden con las cuentas de la Corona ${ }^{14}$ - no sólo proporcionan datos fiscales, sino también jurídicos y sociales, indicando la incidencia del suicidio a lo largo de varios siglos.

No se ha encontrado referencia alguna al tema en los escasos testimonios de sínodos bajomedievales celebrados en la diócesis pamplonesa, así como tampoco en las ordenanzas municipales navarras. Aunque sí despuntan, en cambio, algunas noticias relativas a hallazgos de cadáveres, muertes accidentales y suicidios en los fueros de algunas villas del reino ${ }^{15}$, que tipifican las penas a aplicar sobre dichas muertes. Esta misma falta de medios para conocer el alcance de esta cuestión también es subrayada por autores

\footnotetext{
${ }^{12}$ Laura VIVANCO, Death in fifteenth century Castile: ideologies of the elites, Woodbridge, Suffolk (Gran Bretaña)-Rochester, NY (Estados Unidos), 2004, pp. 64-98.

${ }^{13}$ Fernando VIDEGÁIN AGós, La muerte en Navarra a través de los siglos, Pamplona, 1992. Asimismo, debe destacarse el artículo de Angel RODRIGUEZ SÁNCHEZ, Morir en Extremadura Una primera aproximación, "Norba", 1 (1980), pp. 279-297 que dedica un pequeño epígrafe a tema del suicidio en la época moderna en las páginas 286-287.

${ }^{14}$ Comptos del Reino de Navarra, conservados en el Archivo General de Navarra. Las noticias de suicidios han aparecido en los denominados "documentos" - cédulas y órdenes que consisten en recibos de pagos - y "registros"-libros donde se disponen los balances de las cuentas (tanto gastos como ingresos) - de las diferentes cámaras y hostales reales, así como de la administración territorial del reino. (Publ. J. R. CASTRO, Catálogo del AGN. Comptos. Documentos. Vols. I a $X X X V I$, vol. I, pp. 10-15).

${ }^{15}$ Así en el Fuero de Tudela (datado entre 1247 y 1271), Libro V, Cap. 142, "Del qui mata a si mesmo". Qui se adoba con naualla a si mesmo o se sangra con flegino e se mata assi mesmo no y a calonia. Vid. Angel J. MARTIN DUQUE, Hacia la edicion critica del Fuero de Tudela CENTRO DE ESTUDIOS HISTÓRIĆOS, Transcripción con arreglo al Ms. 11-2-6, 406 de la Academia de la Historia de Madrid; José Luis LACRUZ BERDEJO, Indice Analítico, "Revista Jurídica de Navarra”, 4 (1987), p. 60. En los fúeros de la Alta Edad Media también son regulados algunos aspectos como los hallazgos de cadáveres y las muertes accidentales.
} 
como Jean-Claude Schmitt ${ }^{16}$, Georges Minois ${ }^{17}$, Ariel Guiance ${ }^{18}$ o Alexander Murray $^{19}$, si bien las referencias que han hallado en sus pesquisas parecen ser más variadas que las navarras.

\section{CONCEPTO DE SUICIDIO}

Aunque algunos autores aseguran que la palabra "suicidio" surge propiamente en el siglo XVIII y que no existe como tal en la Edad Media ${ }^{20}$, Alexander Murray aporta una teoría muy diferente; pues indica que la palabra "suicida", entendida como "asesino de sí mismo", ya había sido utilizada por Walter de Saint Victor hacia 1178 en su obra De quator labyrinthos Francine, en el curso de una polémica entre este agustino y Abelardo ${ }^{21}$.

Esta denominación no caló en el discurso medieval, donde el tema del suicidio se ocultaba intencionadamente, siendo empleadas en su lugar una serie de expresiones eufemísticas que, al igual que en Europa occidental, también aparecen en los documentos navarros ${ }^{22}$ : ... eilla mesma se dapno ${ }^{23}$, desesperada de la gracia et misericordia de nostro seynor Dios indubto del diablo, se ovies eill mesmo es enforcado et dapnado ${ }^{24}$....homicida deilla

${ }^{16} \mathrm{~J}$.-C. SCHMITT, Le suicide au Moyen $\hat{A} g e$, p. 4 . Los documentos que ha trabajado son: registros de justicia de París, letras de remisión y crónicas coetáneas. Han sido confrontados con referencias literarias, exempla, textos normativos y noticias de la iconografía religiosa.

${ }^{17}$ G. MiNOIS, History of Suicide, p. 1 encuentra su documentación mụy frạgmentada, en archivos judiciales principalmente, aunque la coteja con otra, como legislacion civil y canónica y con la teoría doctrinal de la Iglesia. Asimismo, con memorias, crónicas, diarios privados y obras literarias.

${ }^{18}$ A. GUIANCE, Los discursos sobre la muerte, p. 360. Las fuentes documentales que utiliza son relatos milagrosos, actas conciliares visigóticas y la normativa civil castellana de Alfonso $\mathrm{X}$ l Sabio.

${ }^{19} \mathrm{~A}$. MURRAY, La grande mélancolie du Moyen Âge, $\mathrm{p}$. 34. Y The Violent against Themselves, pp. 41-42, 97-119, 120-125, 132-138, 139-141, 144-148. Las noticias manejadas por este autor han sido: procesos verbales de los tribunales, fuentes judiciales de carácter civil y religioso, crónicas y narraciones religiosas (hagiografías, milagros de santos). Estas dos clases de documentos nos muestran imágenes muy distintas del suicidio. Mientras que a los de carácter jurídico les interesan los aspectôs referentes a los cadáveres (como la hora y el lugar de la muerte la edad y la fortuna del malherido) los relatos de milagros nos comunican las motivaciones del suicida para darse muerte.

${ }^{20}$ Según J.-C. SCHMITT, Le suicide au Moyen Âge, p. 4, G. MinOIS, History of Suicide, p. 4 y A. GUIANCE, Los discursos sobre la muerte, p, 360 , no será hasta 1734 , en Francia, de la mano cambios mentales operados a raíz de la Revolución Industrial y del pensamiento racionalista que favorecieron el individualismo.

${ }^{21}$ Esta palabra reapareció nuevamente en la obra Religio Medici publicada en 1637 por Sir Thomas Browne, de donde pasó a Francia. Cfr. A. MURRAY, The Violent against Themselves, pp. 38-40.

${ }^{22}$ Recogidas por J.-C. SchmitT, Le suicide au Moyen Âge, p. 4: être homicide de soi-même, s'occir sol-même, se meurtrir («ser homicida de sí mismo», «matarse a sí mismo», «dañarse»).

${ }^{23}$ AGN, Comptos, Registros, 217, fol. 267 r., año 1392.

${ }^{24}$ AGN, Comptos, Documentos, caj. 69, n. 39, II, 21 de Agosto de 1393.-Pamplona. 
$m e s m a^{25}$. Todas ellas hacen referencia a la idea de quitarse la vida ${ }^{26}$, matar$\mathrm{se}^{27}$. Con este acto, el suicida, además de dañar su cuerpo, perjudicaba su alma, pues perdía el derecho a la salvación eterna, por haber cometido el más grave delito, matar una vida, ya que la muerte física es un acto que sólo compete a Dios. Por todo ello, el suicida era considerado, al mismo tiempo, como víctima y asesino, por tanto, pecador y criminal y como tal era castigado $^{28}$.

La concepción del suicidio durante la Edad Media se revistió de un tono profundamente negativo y así los transmiten las fuentes de carácter legislativo y punitivo. Lo que ha sido debido, fundamentalmente, a la profunda significación religiosa que contiene este acto por el cual se rehúsa el don divino de la vida y se establece una brusca ruptura de las relaciones humanas que ha consolidado la víctima con su comunidad ${ }^{29}$.

El mundo griego expresó una gran diversidad de opiniones ante la idea del suicidio. Algunas corrientes filosóficas como el pitagorismo se opusieron a la muerte voluntaria. Aristóteles expresó igualmente su condena por creer que era una injusticia cometida contra uno mismo y contra sus propios padres; un acto de cobardía frente a las dificultades de la vida. Por su parte, Platón en Las Leyes matizó su rechazo al suicidio admitiendo ciertas excepciones, como el caso de enfermedad dolorosa o incurable. Frente a ellos los cínicos, los epicúreos y los estoicos defendieron el derecho de todo individuo a poner fin a una vida que devenía en penosa (terminal, degenerati$\mathrm{va}^{30}$.

${ }^{25}$ AGN, Comptos, Documentos, caj. 174, n. 34, I, 9 de Agosto de 1409.-París.

${ }^{26}$ Según el Diccionario de María Moliner, "matar" podría derivar del latín vulgar mattare (de mattus, estúpido). Véase María MoLINER, Diccionario de uso del español, Madrido, 1998. «Quitar la vida a alguien o algo. Morir alguien en un accidente. Suicidarse». La definición de homicidio que dan Las Partidas es muy similar a ésta, principalmente en el concepto: Homicidium en latín tanto quiere decir en romance como matamiento de ome. Hay tres clases: Primera, cuando mata un hombre a otro sin razón. Segunda, cuando lo hace defendiéndose; y tercera, cuando es casualmente. Vid. Ignacio VELASCO PÉREZ, Las Siete Partidas del sabio rey D. Alonso, Madrid, de él, p. 606. Y'Alfonso X "el Sabio"; Gregorio LOPEZ (glosadas por), Las Siete Partidas del Sabio Rey Don Alonso el Nono, Madrid, 1985, vol. III: "Que cosa es omezillo, e quantas maneras son del". Homicidium en latin tanto quiere dezir en romance como matamiento de ome. E deste nome fue tomado omezillo según lenguajes de España. E son tres maneras del. La primera es quando mata un ome a otro tortizeramente. La segunda es quando lo faze con derecho tornando sobresi. La tercera es quando acaesce por ocasión. E de cada una destas maneras diremos en las leyes de aqueste titulo.

${ }^{27}$ Suicida, proveniente del latín sui de sí mismo, y -cida, a semejanza de homicida. «Se aplica al que se suicida». Suicidio, derivado del latín sui de sí mismo y -cidio, a semejanza de homicidio. "Acción de matarse a sí mismo». Véase María Moliner, Diccionario de uso del español.

${ }^{28}$ A. GUIANCE, Los discursos sobre la muerte, p. 359 y J.-C. SCHMITT, Le suicide au Moyen Age, $\mathrm{p}_{\dot{\mathrm{C}}} 4$. También en L. VIVANCO, Death in fifteenth century Castile, $\mathrm{p} .75$ haciendo referencia a las disposiciones de Las Siete Partidas. Sin embargo, en la época medieval se tuvo una concepción muy distinta del suicidio en el mundo clásico, hasta el punto de que, en numerosas concepcion muy distinta del suicidio en el mundo clásico, hasta el punto de que, en numerosas ocasiones, se revistió de un sentimiento de admiración y respeto relacionado con la salvaguarda del honor y la fama que traspasó las fronteras y que incluso tuvo eco en la literatura de la epoca principalmente en la novela y épica caballerescas. Tambien el suicidio femenino fue aceptado como una forma de salvaguardar el honor y la virtud de la mujer, en caso de peligrar su castida
En esta misma obra se hace un repaso a estos interesantes asuntos, Véase idem pp. 90-97.

${ }^{29} \mathrm{G}$. MINOIS, L'historien et la question du suicide, p. 24.

${ }^{30}$ Ibidem. 
En Roma, durante los primeros tiempos de la República el suicidio era una muerte maldita que empujaba a la ocultación del cadáver en caso de ahorcados y de crucificados ${ }^{31}$. La penetración de las ideas griegas en el siglo I a. C., especialmente del estoicismo, entre las élites intelectuales motivó una gran libertad de comportamiento: la vida no era ya ni un don ni tenía un matiz sagrado, por lo que cada uno podía disponer de la suya a su propia elección. Personalidades tan importantes como Cicerón o Virgilio creyeron que cada sujeto podía tener unos motivos legítimos para optar por el suicidio ${ }^{32}$.

A partir del siglo II, con la llegada al poder de la familia Flavia se produjo una transformación de las relaciones políticas entre los gobernantes y los gobernados. A un mismo tiempo, estas circunstancias coincidieron con una corriente ideológica que denostaba el acto suicida. Todo ello, junto a la crisis económica que comenzó en esta época, produjo una oposición creciente al suicidio y una valoración negativa del mismo ${ }^{33}$. Oposición que se difundió mayoritariamente debido a que las grandes élites romanas fueron las únicas depositarias de las influencias filosóficas griegas que defendían y valoraban el suicidio frente a la gran masa de la población que siguió manteniendo las antiguas creencias supersticiosas en torno a esta cuestión ${ }^{34}$.

Las primeras medidas legales ante la cuestión tienen cabida en el Concilio de Cartago (348), donde la Iglesia condena oficialmente la muerte voluntaria en reacción a movimientos heréticos como el Donatismo, que defendía el martirio voluntario. La máxima autoridad sobre la materia reposará durante siglos en las teorías de San Agustín (a través de su obra De civitate Dei), que muestra el endurecimiento de la posición de las jerarquías eclesiásticas sobre la cuestión del suicidio; quienes terminan con su vida son considerados cobardes, incapaces de resistir las pruebas de la vida o el sufrimiento y el dolor producidos por una enfermedad. Además, desde un prisma cristiano afirma que la vida es un regalo sagrado de Dios y, por lo tanto, sólo a Él pertenece darle fin ${ }^{35}$.

Durante las centurias siguientes se refuerza esta doctrina a través de una abundante codificación de normativas civiles y canónicas, tales como la Lex Romana Visigothorum (s. VI), Concilios de Braga (563) y de Auxerre

\footnotetext{
${ }^{31}$ Porque sus cadáveres no podían ser enterrados. En Jean-Louis VoIsIN, Rome ou le culte de la mort volontaire, "L'histoire", 189 (1995), p. 33.

${ }^{32} \mathrm{G}$. MINOIS, L'historien et la question du suicide, p. 24.

${ }^{33}$ J.-L. VoISIN, Rome ou le culte de la mort volontaire, p. 33. Y G. MINOIS, L'historien et la question du suicide, p. 24 donde indica que, a partir del siglo II, la legislación se endurece notablemente por razones fiscales: se producen numerosos suicidios de romanos ricos amenazados por procesos y condenas que llevan consigo la confiscación de sus bienes para evitar así la ruina familiar.

${ }^{34}$ Así, el suicidio en Roma es concebido como gesto esencialmente aristocrático, una tradición que las grandes familias se transmiten de generación en generación; es el acto, por excelencia, de un hombre libre, aunque también se prođuzcan grandes suicidios masivos entre esclavos. J.-L. VoIsIN, Rome ou le culte de la mort volontaire, pp. 32-33.

${ }^{35}$ Con esta teorías se pone fin a las cuestiones que surgieron en los primeros tiempos del cristianismo en torno al martirio voluntario que, en algunos casos, vinieron a justificar algunos tipos de suicidio (por ejemplo, en caso de rapto de una doncella). Vid. G. MINOIS, History of Suicide, pp. 26-27 y 28. También explica, de forma muy detallada, la doctrina de San Agustín, A. MURRAY, The Curse on Self-Murder, pp. 113-117.
} 
(578) - que condenan todos los tipos de suicidio y prohíben ofrendas y misas por los suicidas - y de tratados escritos por juristas y canonistas como San Bruno - que denomina a los suicidas "mártires de Satán" - o San Buenaventura - que, siguiendo a San Agustín, ve un excesivo amor propio en quienes se suicidan-. Alejandro de Hales, por su parte, abomina del suicidio alegando que bajo ningún pretexto es legítimo matarse uno mismo ${ }^{36}$. La otra gran figura que goza de autoridad sobre el tema es Santo Tomás de Aquino, que en la Summa Theologica define su postura ${ }^{37}$. En términos muy semejantes a los vistos manifiesta su absoluta oposición al suicidio con tres razones. En primer lugar, porque es una ofensa contra natura y contra la caridad ya que toda persona posee una natural inclinación para vivir y amarse a sí misma y a sus semejantes. En segundo lugar, el acto suicida es un ataque contra la sociedad pues todo hombre pertenece a una comunidad, dentro de la cual juega un papel determinado. Y en tercer lugar, porque es la más grave ofensa que se puede cometer contra Dios, propietario de la vida humana ${ }^{38}$.

Para un hombre cristiano es, por tanto, absolutamente imposible comprender que una persona pueda elegir el suicidio como alternativa a una serie de sufrimientos que pueden llevarle a aborrecer su vida ${ }^{39}$. El suicidio es el acto que pone fin a toda esperanza, ya que tras él se cierne inevitablemente la condenación eterna que le privará totalmente de la entrada en la Gloria Celestial.

\section{DIMENSIÓN DEL SUICIDIO Y DE LA MUERTE ACCIDENTAL}

Las noticias útiles referentes al suicidio que se han hallado en los Comptos del Archivo General de Navarra - datadas desde finales del siglo XIII hasta las postrimerías del XV-constituyen un total de 33, a las que se debe añadir una tentativa de suicidio. De este volumen documental, 20 referencias aluden a suicidio masculino, mientras que las cifras que señalan a mujeres son sensiblemente inferiores, contándose $13 \operatorname{casos}^{40}$. Todo ello puede ponerse en correspondencia con los datos que ofrecen Jean Claude Schmitt o Alexander Murray y que también permiten comprobar una mayor incidencia de este fenómeno entre hombres ${ }^{41}$.

${ }^{36}$ G. MinOIS, History of Suicide, pp. 28-32. Igualmente A. MuRRAY, The Curse on SelfMurder, pp. 221-224.

${ }^{37}$ John P. DOYLE (trad., introd. y notas), Francisco DE VITORIA, Relection on homicide \& Commentary on Summa theologiae II ${ }^{-}$II ${ }^{e}$ Q. 64 (Thomas Aquinas), Milwaukee (EE.UU), 1997, pp. 169-184.

${ }^{38} \mathrm{G}$. MINOIS, History of Suicide, p. 33. Teorías más completas en A. MURRAY, The Curse on Self-Murder, pp. 229-231. Tambien comentado por L. VIVANCO, Death in fifteenth century
Castile, pp. $85-86$.

${ }^{39}$ G. MinoIs, History of Suicide, p. 38.

${ }^{40}$ Suponen, por tanto, un $60 \%$ de suicidio masculino frente a un $39 \%$ de suicidio femenino.

${ }^{41} \mathrm{~J}$.-C. SCHMITT, Le suicide au Moyen Âge, p. 5. Y A. MURRAY, La grande mélancolie du Moyen Age, p. 34. Ambos autores indican que los hombres se suicidan unas 3 veces más que las mujeres. Sin embargo, los datos manejados para el caso navarro indican una mayor equidad. 
Pese a todo, los datos facilitados por estos testimonios no son todo lo explícitos que se desearía. El problema estriba en que, en la mayor parte de los casos, sólo indican la fecha de expedición de la orden y ni los escribanos ni la administración tienen apenas en cuenta otros detalles como las datas y horas de las muertes, que no les son demasiado útiles. Principalmente registran las causas o las circunstancias de la misma, que les permitirían conocer si se podía proceder a la confiscación efectiva de los bienes del suicida, así como a la aplicación de castigos corporales y espirituales a su cadáver.

Como se ha dicho, las fechas en que se llevaron a cabo estos suicidios no aparecen indicadas - sólo en 11 casos $^{42}$ - como tampoco las horas, salvo alguna excepción. Por lo tanto, no es posible realizar una contabilidad exhaustiva que hubiera permitido acercarse de una manera más exacta al conocimiento y circunstancias del suicidio. No obstante, estas escasas noticias permiten formarse una idea bastante aproximada de la vivencia del suicidio en la Navarra bajomedieval. Algunas de las informaciones extraídas de los textos indican dos formas de datar los suicidios. En unos casos, son referencias vagas, como esta que sigue:

Nos avemos entendido que agora pocos dias ha Johanexca de Benadis morant en Amenduyx en la parroquia de la poblacion, desesperada de la gracia et misericordia de nostro seynor Dios indubto del diablo que a seydo su conseillo et ministro se es de eill mesmo enforcado et dapnado ${ }^{43}$

Otros testimonios son más explícitos y detallados, y nos indican las fechas exactas en que se producen los suicidios ${ }^{44}$, predominando entre ellos la época estival: ...por razon que el dicto Johan Yeneguiz se enforco primero dia deste mes dAgosto en que estamos... ${ }^{45}$

${ }^{42}$ En el $33 \%$ de los documentos que hacen referencia a suicidios (11 de 33 suicidios probados). Frente al $72 \%$ (39 de 54 casos) de J.-C. SCHMITT, Le suicide au Moyen Age, p. 9 . En la mayor parte de los documentos obtenidos por A. MURRAY tampoco aparecen las menciones 413-420.

${ }^{43} \mathrm{AGN}$, Comptos, Documentos, caj. 61, n. 57, VIII. 28 de Julio de 1391.-Pamplona. En el Catálogo de Comptos el personaje es denominado "Johanexca de Benadis" mientras que Videgáin lee "Juan Exea de Benadis". Véase F. VIDEGÁIN, La muerte en Navarra, p. 151, nota XViIII, n. 366 .

${ }^{44}$ Gracia Martínez de Belascoáin, mujer de García Périz de Azanza, herrero de Puente la Reina,lo hace el 29 de Agosto del año 1396. (AGN, Comptos, Documentos, caj. 72, n. 4, XVIII). Lope Iñiguez, vecino de Villava, ... el sabado XXIII ${ }^{\circ}$ dia del mes de junio postrerament passado... del año 1397 . (AGN, Comptos, Documentos, caj. 75, n. 54). Jamila, judía, mujer de Jento Franco, ...el sezeno dia del mes de abril postremerament passado... del año 1400 . (AGN Comptos, Documentos, caj. 85, n. 30). Y Navarra de Roncal, ...en el mes de junio postremerament passado... del año 1409. (AGN, Comptos, Documentos, caj. 174, n. 34, I).

${ }^{45}$ AGN, Comptos, Documentos, caj. 72, n. 1, VI, 11 de Agosto de 1396.-Irache. 
En una ocasión, también se hace mención expresa de la hora en que se produjo el fatal accidente, citándose la noche o, más concretamente, la medianoche ${ }^{46}$, además del día exacto de la desgracia, constituyendo así un testimonio excepcional dentro del panorama navarro:

\begin{abstract}
Como el XXIX ${ }^{0}$ dia del mes de Agosto que postremerament passo Gracia Martiniz de Blascoayn, muger que fue de Garcia Periz de Açança, ferrero morant en la dicta villa de la Puent, temptada por el diablo o eilla sabia por que, se dize saillio de casa casi a media noche et se echo en la agoa do depues fue faillada afogada ${ }^{47}$.
\end{abstract}

A la vista de los exiguos resultados, se concluye que buena parte de los suicidios incluídos en este estudio tuvieron lugar en los meses de Junio y Agosto, así como en Abril, lo que viene a coincidir con lo que en su día señaló Jean Claude Schmitt ${ }^{48}$. En cuanto a las horas, no puede deducirse que durante la noche se produjeran más suicidios, ya que la única noticia de que se dispone no puede imponerse como un hecho generalizado.

En otro orden de cosas, los procedimientos de suicidio sí aparecen en todas las ocasiones muy bien descritos. El ahorcamiento es el método más frecuentemente elegido ${ }^{49}$ : En Guerguetiaynn, de Pero Ayvar, que se enforco ayll mesmo ${ }^{50}$...In villa de Mendavia (...) Petro Santofuego qui se suspendit... ${ }^{51}$. O ...por razon que Gracia dIracheta enforco su cabeça ${ }^{52}$. Sin duda, el caso más espectacular es el de Jimeno, hijo de Jimeno don Elfa, vecino de Cascante:

...por razon que el dicho Semeno, temptado et inducto por el diablo un anno ha o mas se enforco de la cuerda de la campana de la yglesia de

${ }^{46}$ J.-C. SCHMITT, Le suicide au Moyen Âge, p. 10. A. MURRAY, The violent against Themselves, pp. 417-420. Ambos autores señalan que los más numerosos casos de suicidios se producen a la medianoche y al alba.

${ }^{47}$ AGN, Comptos, Documentos, caj. 72, n. 4, XVIII. 13 de Septiembre de 1396.-Estella. Y AGN, Comptos, Registros, 231, fol. 255v, 14 de Septiembre de 1396.

${ }^{48}$ J.-C. SCHMITT, Le suicide au Moyen Âge, pp. 9-10 donde indica que estas fechas pudieron estar influidas por elementos como la intensidad del trabajo del campo (mes de Junio), calores sofocantes del verano (Agosto), rigores del ayuno y la penitencia (Abril y Diciembre). Las conclusiones que A. MURRAY ha obtenido de sus investigaciones son muy similares, The Violent against Themselves, pp. 413-416.

${ }^{49} 20$ casos $(60 \%): 13$ hombres (39\% del total de suicidas) y 7 mujeres $(21 \%)$. Sigue la tónica del territorio francés, J.-C. SCHMITT, Le suicide au Moyen Age, p. 5 , donde indica que esta causa supone un $60 \%$ de los suicidios. A. MURRAY, The Violent against Themselves, pp. 403-413, también asegura que éste es el método mayoritario de suicidio en Europa con unos datos aproximados de un $52 \%$, (de los cuales un $49 \%$ pertenecen a Inglaterra y un $62 \%$ a Francia).

${ }^{50}$ AGN, Comptos, Registros, 10, fol. 69 v., año 1306.

${ }^{51}$ AGN, Comptos, Registros, 13, fols. 189 r. y 189 v., año 1309.

${ }^{52}$ AGN, Comptos, Registros, 25, fol. 157 r., año 1329.-Burgo de San Cernin. 
Cascant et de si fue fayllado muerto como hombre desesperado de la gracia de Dios ${ }^{53}$.

La precipitación a ríos o a pozos es la segunda modalidad de suicidio, con un porcentaje aproximado del $35 \%^{54}$ : ...por razon que fue faillada afogada en un pozo et dizian que eilla mesma se dapno ${ }^{55}$ o bien ....Maria Petroch, muger de Garcia Lopiz vezino de Garde, que fue desesperada de la gracia de Dios eilla misma se dapno e afogo en lagoa ${ }^{56}$.

También existen dos noticias referentes a suicidio por corte de la garganta, con su consecuente desangramiento ${ }^{57}$ : ...et otrossi que le significaba que Bleso Peris, baylle de Çintrueynnego, tenia preso se tayllo la gola de que era muerto ${ }^{58}$.

$\mathrm{Y}$ finalmente se cuenta con un testimonio excepcional en el mundo medieval, y, al mismo tiempo, estremecedor, por el que se informa de tres ladrones que, estando encerrados en prisión, se suicidaron quemándose vivos:

Item primis por despens de Salvador de Ontit e de Yenego su compayhero que fueron presos la viespra de Pascoa de Mayho qui passo avio dos aynhos. E finaron en la persona que eylhos messmos se dieron fuego miercoles enpues la fiesta de Santa Lucia, qui en este anho present passo por DCCCCta.XXX dias que fueron en la preson por cada dia sendos dineros de mesion a cada uno de eylhos CLV.co. florines.

Item por despens de Johan Martiniz de Mendoça que fue preso en Torres en la sozmerinia de Val dElortz por muchos robos e furtos que avia fechos e ragro VII.te. meses en la prison e matose con aqueylhos de muert por CCXIII dias que rogro en prison e por cada dia VII dineros con XXV sueldos II dineros que costo de laqua de la prison a cabo de vn mes que morio... 59

Los lugares donde se producen estas muertes también aparecen recogidos en algunos testimonios. Así, el más citado es la casa, bien propia

${ }^{53} \mathrm{AGN}$, Comptos, Documentos, caj. 12, n. 157. 15 de Septiembre de 1356.-Pamplona. Este documento es uno de los pocos que menciona un lugar de suicidio situado fuera de la propia casa (salvo en los casos de ahogamiento en río o pozo), y, además, insólito: la iglesia parroquial.

${ }^{54} 15$ casos en total (45\%): 9 hombres (27\% del total de suicidas) y 6 mujeres $(18 \%)$. J.-C. SCHMITT, Le suicide au Moyen Âge, p. 5 donde indica un porcentaje de $22 \%$. Según A. MURRAY The Violent against Themselves, aproximadamente un $37 \%$ de los suicidas escogerían esta forma The Violent against Themselves, aproximadamente un $37 \%$ de los suicida
de morir, de los cuales un $31 \%$ son ingleses y un $22 \%$ son franceses.

${ }^{55}$ Sancha, hija de Sancho del Huerto, vecina de Los Arcos. AGN, Comptos, Registros, 220, fol. 261 v., año 1393.

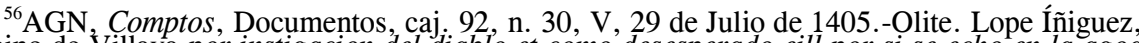
vecino de Villava por instigacion del diablo et como desesperado eill por si se echo en la agoa et se enfogo e que assi lo faillaron muerto en la agoa con una su saya vestida.., se suicidó eP 23 de Junio de 1397. (AGN, Comptos, Documentos, caj. 75, n. 54).

${ }^{57}$ Suponen un $6 \%$ de los suicidios, frente a un $8 \%$ de los casos de J.-C. SCHMITT, Le suicide au Moyen Age, p. 5 , o un $26 \%$ de A. MURRAY, The Violent against Themselves, p. 405.

${ }^{58}$ AGN, Comptos, Registros, 51, fol. 24 r., año 1344.

${ }^{59}$ AGN, Comptos, Registros, 38-1, fol. 113 v., año 1337. 
o ajena ${ }^{60}$. De igual modo la iglesia del pueblo es también, en un caso, elegida para acabar con la propia vida ${ }^{61}$. Y, asimismo, otros espacios situados en las cercanías de la casa como pozos ${ }^{62}$ y ríos $^{63}$ de la localidad.

\begin{abstract}
A nostra noticia es venido como el sezeno dia del mes de abril postremerament passado Jamila judia, muger de Janto Franquo, judio de sangre, por instigacion del diablo et deseperada de la missericordia de Dios se echo en un pozo que es en la carniceria de la dicha villa [de Sangüesa] et la faillaron afogada con una saya bestida por la quoal cosa todos sus bienes son qonfiscados a mos segunt dicho fuero usso et costumbre de nostro regno por fazer deillos a nostro plazer et voluntat...64
\end{abstract}

Valtierra:

O, incluso, el lagar del pueblo, como sucede con Catalina, vecina de

Como Cathelina muger de Bernart Periz, vezino et morador en Valtierra, un dia del mes de junio postremerament passado por su ventura o por temptacion diabolica se sea enforcada en el dicho lagar de Valtierra ${ }^{65}$.

En el caso de delincuentes o criminales es frecuente que se produzca este suceso en la propia prisión:

....como Loppe Miguel de Billava, vezino de nostra ciudat de Pomplona, pocos dias ha seyendo en nostra preson de nostra ciudat de Pomplona (borrado) ensogado assi mesmo por el quoal delicto et maleficio segunt derecho et costumbre de nostro regno todos e quoalesquiere bienes tanto muebles como heredades que f(borrado) del dicto Loppe Miguel son afiscados et aplicados a nostra corona et son mas para fazer daquillos a nostra propria voluntat...6

${ }^{60}$ Cinco noticias. En su propia casa, Domingo de Alfaro, vecino de Calchetas (Tudela). (AGN, Comptos, Registros, 19, fols. 1 v. y 4 r., año 1319). O Elvira Fueras, mujer de Andres Dondat, vecina de Artajona ...enforcada dentro en la casa do fincava e morava e aya asi seyda
trobada enforcada. (AGN, Comptos, Documentos, caj. $94, \mathrm{n}$. 25 , VII 10 de Mayo de $1407 .-$ trobada enforcada. (AGN, Comptos, Documentos, caj $94, \mathrm{n}_{\text {. }}$. 25 , de los Arquos, morador en Elite) ila que se forquo eyll mesmo en la casa del dicho su padre en la juderia dEsteylla. (AGN, Esteypto que se forquo eyistros, 49 , fol. 282 r., año 1343).
Compto

${ }^{61}$ Caso de Jimeno, hijo de Jimeno don Elfa, vecino de Cascante. (AGN, Comptos, Documentos, caj. 12, n. 157, 15 de Septiembre de 1356.-Pamplona). ${ }^{62}$ Cuatro noticias, como el caso de Martico de Latasa que se ahogó en el pozo de los
jacobinos de Pamplona. (AGN, Comptos, Documentos, caj. 30, n. 87, I, I5 de Junio de $1376 .-$ Pamplona).

${ }^{63} 5$ referencias, entre las que destacan: De Johan de Liçarraga peilletero, vezino de Pomplona que fue faillado afogado en la agoa et rio de Pomplona et dizlendo eill mesmo ser dapnado et fueron emparados todos sus bienes et de mandamiento de la seynnora reyna. (AGN Comptos, Registros, 244 , fol. $239 \mathrm{r} .12$ de Septiembre de 1398). O doña Oria Pérez de Ustés: desor razon que la dicha dona Oria Periz se affogo en una agoa como muger dapnada e

${ }^{64} \mathrm{AGN}$, Comptos, Documentos, caj. 85, n. 30, 14 de Mayo de 1400.-Olite.

${ }^{65}$ AGN, Comptos, Documentos, caj. 174, n. 34, II, 14 de Septiembre de 1409.-Pamplona.

${ }^{66} \mathrm{AGN}$, Comptos, Documentos, caj. 75, n. 44, 11 de Junio de 1397. Véase otro caso en nota 60. También en Aragón se recogen noticias de características similares. Así, en 1485 dos presos de encearcelados en el castillo de la Aljafería de Zaragoza (que formaban parte de un proceso instruido a un grupo de judíos conversos por Fray Pedro de Monte Rubio, prior del convento de dominicos de Dueñas) se suicidaron para evitar el tormento de la Inquisición. Uno fue micer 
En cuanto a las clases sociales a las que afectaba el suicidio, no se han encontrado datos que puedan hacer creer que fuese extensivo a todos los estamentos, aunque afectaba especialmente a la etnia judía, con 4 noticias ${ }^{67}$. Este grupo, frecuentemente elegido como "chivo expiatorio" de los problemas y tensiones del mundo cristiano, estaba sometido a una fuerte presión, especialmente en la época de las pestes, por lo que el elevado número de suicidios se comprende como vehículo de escape de una situación en muchos casos insoportable ${ }^{68}$. Asimismo, los restantes personajes conocidos parecen corresponder a comerciantes y artesanos ${ }^{69}$ y a campesinos ${ }^{70}$, especialmente, seguidos por delincuentes ingresados en prisión $^{71}$. No existen, pues, referencias que puedan indicar si el clero se vio afectado por estos problemas, así como tampoco si esto se produjo entre las clases más pudientes ni el ambiente cortesano $^{72}$, quizá porque las fuentes lo silencian ${ }^{73}$. La ausencia de

Francisco de Santa Fe; el otro Juan Abadía, que falleció por asfixia, a causa de una lámpara de cristal que trató de engullir. Véase Monique COMBESCURE THIRY' (introd. y transc.), Miguel Angel MOTIS DOLADER (present. y estud. preliminar), El Libro Verde de Aragón, Zaragoza, 2003 , pp. 204, 206, 209. Y Henry Charles LEA, A History of the Inquisition of Spain, Nueva York, 1966, vol. I, p. 258, nota 3.

${ }^{67}$ Juce Envolat, hijo de Mose Envolat, judío de Los Arcos, residente en la judería de Estella, que se ahorcó. (A'GN, Comptos, Registros, 49, fol. $282 \mathrm{r}$. a $282 \mathrm{v}$., año 1343 ). Vidal judío de Mendavia que se ahogó en el río Ebro. (AGN, Comptos, Papeles Sueltos $2^{a}$ Serie, leg. 2, n. 115 II y III. 16 de Julio de 1381). Jamila, mujer de Jento Franco, judío de Sangüesa, que se arrojó a un pozo. (AGN, Comptos, Registros, 258, fol. 230 r., 14 de Mayo de 1400 y AGN, Comptos, Documentos, caj. 85, n. 30). Y Salomón, llamado Carrasco, judío bufón del rey Carlos III, que se arrojó por el talud del palacio de Olite el 27 de marzo de 1414. (ÄGN, Comptos, Documentos, caj. 113, n. 38, II, cit. Fernando VIDEGÁIN AGÓs, La muerte en Navarra, pp. 151-152, nota 161).

${ }^{68} \mathrm{G}$. MinOIS, History of Suicide, p. 18. Pilar LEÓN TELlo, Judíos toledanos víctimas de la peste negra en "Sefarad", XXXVII,' 1977, p. 333. Béatrice LEROY en Los judíos de Navarra en la Baja Edad Media, Madrid, 1991 , pp. '140-144 también hace referencia a las agresiones y matanzas que se llevaron a cabo en Navarra contra las juderías del reino (algunos años son 1234 1328,1358 ó 1361). Véase en nota 67 también el caso de dos conversos en Zaragoza que se suicidaron para evitar los tormentos de la pena que se les había impuesto.

${ }^{69}$ Juan Íñiguez, vecino de Monreal, es mulatero. (AG̣N, Comptos, Registros 231, fol. 256 r., 11 de Agosto de 1396). Gracia Martínez de Belascoáin es mujer de García Pérez de Atanza, herrero de Puente la Reina. (AGN, Comptos, Registros, 231, fol. 255v, 14 de Septiembre de 1396). Juan de Lizarraga, vecino de Pamplona, es pelletero. (AGN, Comptos, Registros, 244, fol. 239 r., 12 de Septiembre de 1398). Y María Pérez de Estánoz, vecina de Pamplona, es mujer de Miguel de Araiz, carnicero. (AGN, Comptos, Registros, 269, fol. 228 v., 1 de Mayo de 1402).

${ }^{70}$ Puede ser así porque no se indica su ocupación, sino tan sólo su condición de vecinos de una determinada localidad, en su mayoría, de ámbito rural: Domenga de Gascue, moradera en Guendulayn, cabo Ripa... (AGN, Comptos, Registros, 217, fol. 267 r., año 1392). Martin Ferrandiz vecino de Larrahona... (AGN, Comptos, Documentos, caj. 69, n. 39, II, 21 de Agosto de 1393.-Pamplona). De Johan Maryn, vezino de Caparroso... (A GN, Comptos, Registros, 275, fol. 235 v., ano 1403 ).

${ }^{71}$ Cinco suicidios en prisión. (Algunos de ellos: AGN, Comptos, Registros, 38-1, fol. 113 v., año 1337. Y AGN, Comptos, Registros, 51, fol. 24 r., año 1344).

${ }^{72} \mathrm{El}$ suicidio de un bufón judío del rey puede ser síntoma de que también se produjesen actos suicidas en la corte, pero que se ocultaban, pues no se ha hallado ninguna otra referencia en la documentación de Comptos. (AGN, Comptos, Documentos, caj. 113, n. 38, II).

${ }^{73}$ Situación que es totalmente diferente respecto a otros espacios europeos, como Francia, donde Schmitt y Minois indican un número significativo de suicidios entre miembros de la corte J.-C. SCHMITT, Le suicide au Moyen Age, pp. 6-7. Y G. MINOIS, History of Suicide, p. 18. A.
MURRAY, The Violent against Themselves, pp. 386-399, hace un interesante estudio sobre las condiciones económicas de las personas que se suicidan en el reino de Inglaterra. Concluye que el mayor porcentaje de suicidios se da en las clases más bajas, con un menor poder monetario así como en las medias; frente a ellos, las personas incluídas dentro de las categorías adineradas 
miembros de la nobleza puede deberse a que muchos de ellos realizaban actividades que les permitían liberar sus actitudes violentas o, incluso, disimular las prácticas de suicidio, en otras situaciones tales como guerras o torneos. También la nobleza controlaba la justicia a nivel local, lo que les permitiría encubrir los posibles actos suicidas y hacerlos aparecer como muertes accidentales o bien naturales. Algo similar podría ocurrir con el clero -las pastorales hablan sobre el grave riesgo de tentaciones de desesperación que sufría el clero monástico ${ }^{74}-$, que no podía permitirse el agravio de que uno de sus miembros fuese sometido a ajusticiamiento o a privación de sepultura eclesiástica ${ }^{75}$.

Además de los suicidios definidos existen otras noticias de hallazgos de cadáveres de los cuales no se conocen las circunstancias de la muerte. El temor de que se hubiese producido un suicidio inducía a iniciar una indagación. Así ocurría en algunas ocasiones, como cuando fue encontrado el cadáver de una peregrina a Santiago de Compostela, Colleta de Bonilla, bajo el puente situado entre las localidades de Larrasoaña y Urdániz. De hecho, los bienes que fueron encontrados con ella fueron vendidos para financiar la investigación de las circunstancias de su fallecimiento - llevada a cabo por el notario Miguel Périz de Ciriza por mandato del rey-así como su funeral y entierro.

Karlos por la gracia de Dios rey de Nauarra conte dEureux. A nostro bien amado et fiel procurador fiscal Garcia Martiniz de Leach. Salut nos auemos dado et damos por las presentes por mercet et gutu en la obra de sennior Sant Agustin de Pomplona la suma de nueve francos que fueron trabados sobre Colleta de Bonilla romea la quoal fue faillada muerta de iuso la puent que es enta la Rasoigna et Urdaniz. Et un rocin suyo que fue bendido por Miguel Periz de Ciriça notario et comitido por nos a saber desta muert como qontescio en la suma de quoatro libras et diez sueldos las quoales quoatro libras X sueldos el dicto Miguel Periz ha gastado et diespendido en fazer la inquesta de la dicta muert en la quoal fue por nos ordenado et cometido como dicto es. Si las mandamos que de las dictas sumas de IX francos et de IIII libras X sueldos tengades por quarto et descansado al

constituyen una escasa minoría. Véase tabla en p. 387. Asimismo en pp. 390-395 incluye las ocupaciones y profesiones de estos suicidas. La mayor parte de las noticias provienen de los registros ingleses, seguidos de los franceses. Ambos indican un elevado número de suicidas entre campesinos y artesanos, secundados por profesionales liberales tales como agentes de justicia. Además de una considerable proporción de clérigos y religiosos.

${ }^{74}$ Dice A. MURRAY, La grande mélancolie, p. 35 que los suicidios monásticos existían, aunque eran raros. Sin embargo, están mejor documentados que los de los laicos por la expectación que causaban. Asimismo, explica cómo la vida de un monasterio registraba una predisposición al suicidio porque los monjes estaban sometidos a tentaciones y a lo que ellos mismos denominaban acedia, una suerte de hastío general marcado por un sentimiento melancólico-depresivo que les embargaba después de la comida, según citan algunas fuentes documentales. Los viejos monjes atestiguaban, de igual manera, que cierto humor o talante, podía atacar a los novicios pero tambien a los monjes probados -aunque ellos ya tuvieran experiencia y remedios para salir de la situación-y conducirlos al gesto fatal.

${ }^{75} \mathrm{G}$. MINOIS, History of Suicide, pp. 37-38. A. MURRAY confirma estas teorías en The Curse on Self-Murder, p. 34, indicando que, en el siglo XIV, los cuerpos de los clérigos suicidas, estaban sujetos a una jurisdicción propia, siguiendo así el Derecho Romano, que prohibía que fueran colgados. 
dicto Miguel Periz asumir jamas. Et a meos amados et fieles las gentes oydores de meos comptos et thesoro mandamos que las dictas sumas de IX florines IIII libras $\mathrm{X}$ sueldos por nos dadas et qontadas como dicto es los reciban en compto et rebbaram de vestras receptas por testimonio de las presentes tan solament sin difficultat nin qontrado alguno et dat en Pamplona III $^{0}$ dia dAgosto laynno de gracia Mil .cc nouanta et uno ${ }^{76}$.

Un acontecimiento similar se produjo unas décadas después, cuando fueron descubiertos dos cadáveres de peregrinos en Valcarlos. En este caso, al igual que se hizo en el ejemplo anteriormente visto, Carlos III ordenó que el notario de la corte, Sancho Martínez de Arberoa, viajase a la zona para investigar las causas de dichas muertes y determinar si podían ser enterrados cristianamente $^{77}$.

También se llevaron a cabo una serie de pesquisas cuando fue encontrado el cuerpo de María Pérez de Zudaire, en el interior de su casa y cuyos bienes fueron preventivamente emparados por el preboste de Estella en nombre del rey.

Karlos por la gracia de Dios rey de Navarra e duc de Nemours. A nostro amado e fiel procurador fiscal Lope Lopiz de Bearin. Salut. Por partes de don Eynego, abat dArtaça, Simon de Pomplona, ortelano vezino dEstella, cabeçalleros del ultimo testament de Maria Periz de Cudaire, muger de Johan dUxue, vezinos dEstella que fueron et de don Johan de las Arquas, capeillan, cabeçallero sustituydo al testament del dicho Johan dUxue segunt dizen e nos a seydo suplicando e dado a entender diziendo que la dicha Maria Periz viniendo en los bienes deilla e del dicho su marido en la villa dEstella en su casa por la quoal cosa vos deziendo que eilla mesma se seria dapnada fiese enparar e poner a nostra mano todos sus bienes por el prevost dEstella. Por el quoal embargo eillos non podiendo aver los dichos bienes por usar de la dicha, cabeçalleros nos pidian por merçe serle preveydo de devido remedio, nos entendida su dicha suplicacion sobre aqueilla queriendo prever oviesemos comiendo e mandado a çierto comissio sobre verdat. El quoal fecho a nos relacion por quoanto peresce la dicha Maria por aver seydo de buena vida fama e conversacion sin que otra deseperacion aya ovido sino alguna henfermedat los mandamos firmement que luego vistas las presentes deyxades i desenbarguedes o fagades deyxar e desenbargar los dichos bienes sueltos et quoantos sin detenimiento alguno a los dichos cabeçalleros por usar de la dicha cabeçalleria o de aqueillos que dicho avran en eillos dar asi lo queremos e nos plaze. Data en Olit so nostro sieillo de la chancelleria $X_{V I}{ }^{\circ}$ dia de novienbre Anno a Nativitate Domini $\mathrm{M}^{\mathrm{0}} \mathrm{CCCC} \mathrm{VI}^{\mathrm{0}}{ }^{78}$.

La investigación sobre las causas y circunstancias de una muerte accidental $-\mathrm{o}$ también de un suicidio - es primordial, pues determinaría el

\footnotetext{
${ }^{76} \mathrm{AGN}$, Comptos, Documentos, caj. 61, n. 61, IV, 3 de Agosto de 1391.-Pamplona.

${ }^{77}$ AGN, Comptos, Documentos, caj. 116, n. 31, IV, 20 de Diciembre de 1416.-Olite.

${ }^{78}$ AGN, Comptos, Documentos, caj. 93, n. 66, IV, 11 de Noviembre de 1406.-Olite.
} 
grado de culpabilidad del fallecido ${ }^{79}$. Según indica Alexandre-Bidon para Francia, siempre que se hubiese producido una muerte intervendría el juez. En caso de pelea y de herida mortal, los representantes municipales, jueces, bailes, acompañados de un notario que registraría las declaraciones se desplazaban hasta donde se encontraba el moribundo y volvían más tarde en caso de que éste muriese. De este modo inspeccionaban ocularmente el estado del implicado cuando agonizaba y una vez fallecido y posteriormente examinaban los informes médicos que autorizaban la inhumación. Las pesquisas judiciales se centraban entonces en descubrir la identidad del fallecido los más rápidamente posible, sobre todo si no era conocido en la localidad, buscando parientes que pudiesen reconocerlo. Posteriormente, los agentes administrativos y judiciales se centraban en arrestar y juzgar al culpable de la muerte y en establecer si las heridas habían sido o no la causa directa de dicho fallecimiento, competencia que correspondía al médico "legista" - expresión de Alexandre-Bidon- que actuaba como cirujano y que comunicaba sus conclusiones al notario ${ }^{80}$. Aquí jugaba un importante papel la práctica de la disección del cuerpo, que se habría efectuado con anterioridad a la inhumación. Igualmente, en los casos de muertes sospechosas o violentas como los suicidios o los accidentes, también se apelaba a los oficiales de justicia y a los profesionales de la sanidad, a cirujanos o a barberos, que desde el siglo XIII no podían tratar ocultamente a los suicidas ni a los homicidas sangrientos, sino que estaban obligados a rendir cuenta de dichos sucesos, según lo estipulaba el primer artículo de sus estatutos profesionales. Así pues, los oficiales municipales se hacían responsables de todos los heridos y muertos que se hallasen en la escena de un accidente o de un crimen, palpando y examinando los cuerpos allí mismo para tratar de determinar las causas de la defunción e intentar obtener los primeros indicios de lo que había sucedido. Los fallecidos eran trasladados a un edificio público donde se procedía a abrir el cuerpo. Mediante la observación del color y tamaño de sus fluidos y órganos internos y de sus miembros externos, de la palpación de los mismos, y de la confrontación con la reconstrucción de los acontecimientos previos al deceso, se determinaba cómo había tenido lugar el fallecimiento o el accidente $^{81}$.

Si era considerada como muerte accidental, podía procederse a la celebración de los oficios religiosos por su alma y al entierro de su cuerpo. Así sucede en el caso de un hombre que cayó a un pozo, al que se permitió enterrar cristianamente.

\footnotetext{
${ }^{79}$ Jean de Boutillier ( $\left.† 1395\right)$ aconsejaba que cuando se hubiera producido una muerte por suicidio el oficial de justicia debería iniciar una pesquisa para aclarar los hechọs. No se aplicaría ninguna sentencia a la víctima a menos que el suicida hubiese cometido el crimen para librarse ninguna sentencia a una sentencia judicial, caso en el que recibiría el mismo castigo que se le debía haber aplicado en vida. En G. MINOIS, History of Suicide, p. 40 .

${ }^{80}$ Danièle AleXandre-BIDON, La Mort au Moyen Âge. XIIIe-XVIe siècle, París, 1998, pp. 182-183.

${ }^{81}$ Idem, pp. 183-192.
} 
Item morio Johan fijo de Miguel Gureçe, sabado vigilia de Sant Miguel que se afogo en un poço et dieron me fiadores et mandenlo enterrar a su padre et a Garçia Chaparel ${ }^{82}$.

Al igual que se ordenó con un romero a Santiago de Compostela que se había ahogado en el río Ega a su paso por la localidad de Estella.

\section{(fol. 227 v.)}

Item en el dicho aynno en el mes de Febrero cabo la puent de piedra que es dentro en la dicha villa en el Rio Mayor llamado Egua, se afoguo hun romeo al qual li faillaron en una bolsa una moneda de jaqueses, tresales de Nauarra con dos groses de cada IIII sueldos VI libras V sueldos VI dineros. Item mas hun florin de Florença XXXVIII sueldos. Suma todo VIII libras III sueldos VI dineros prietos que valen a valor VI libras X sueldos IX dineros ob[olos].

(fol. 228r.)

Expensa de este aynno.

...Item mas fue fecha mision en el henterramiento del romero que afoguo fecha por Johan de Mendico carnicero vezino dEstella segun se sigue.

Primo VI coudos et meio de lienço paral suario a III sueldos VI dineros el coudo valen XXII sueldos X dineros.

Item filo para coser el dicho suario, III dineros.

Item las torchas de Santa Maria que ardieron a su enterramiento mermaron III quarteros que valen IIII sueldos VI dineros.

Item fue partido a los clerigos que ailli heran et al que diso la misa $\mathrm{X}$ sueldos VI dineros.

Item al qui fizo la fuesa, XII dineros.

Item fue dado al bacin de la obra et luminaria de Santa Maria de la eglesia de Sant Miguel do eill fue soterrado por su anima V sueldos VI dineros.

Summa la dicha expensa VI libras IX sueldos VII dineros prietos que uallen a blancos CIII sueldos VIII dineros.

Et la recepta es... ${ }^{83}$

Estas muertes eran denominadas por la legislación navarra como “casuales" y no cargaban la pena de homicidio ${ }^{84}$.

Iten nos queriendo usar de misericordia, como dicho es, sequesciendo lo que por el de buena memoria D. Tibalt nuestro predecesor Rey de Navarra, a qui Dios perdone, fue ordenado establecemos et ordenamos, et mandamos por mejoramiento de fuero, et quitamos, et remitimos, et levamos por siempre jamas en remision de nuestros faillimientos et de nuestros predecesores todos los homicidios casuales que acaecieren por non poder o por desaventura en el nuestro regno de Navarra es a saber, por ferida de bestia o caida de ella, o ferida darbol, o caida deill, por afogamiento de

\footnotetext{
${ }^{82}$ AGN, Comptos, Registros, 38-1, fol. 25 r., año 1337.

${ }^{83}$ AGN, Comptos, Registros, 181, fol. 227 v.-228 r., año 1384.

${ }^{84}$ Además del FGN fueron reguladas por fueros locales, como el de Viana (1219): Non peccent homicidium per terminum. Si inuenerit hominem mortuum intus villam aut extra villam nisi ipsi populatores. (Pedro J. DuQue, El Fuero de Viana, "Príncipe de Viana", 35, 136-137 (1974), p. 413).
} 
agua, o por caida de casa, o por caida que alguno ficiere de illa et de todo omicidio que acaesciere por ventura y sin culpa $\&^{85}$.

No obstante, en otras circunstancias no se actúa con tal clemencia, sino que se procedía como si se hubiese cometido un crimen ${ }^{86}$. Así fue en el caso de Eneco de Redín, que había robado unas ropas en Uroz. Mientras era perseguido cayó, de forma imprevista, a la fuente y se ahogó. Tras avisar al gobernador de lo ocurrido, éste prohibió tocar el cadáver y ordenó que fuese puesto en una tabla et echado por lagoa ayuso, atándolo con cuerdas ${ }^{87}$, tal y como se hacía con los suicidas y con los criminales, como se verá en breve ${ }^{88}$.

Por otra parte, cuando se encontraba el cadáver de un suicida, debía notificarse a las autoridades de cada localidad y al merino, que acudirían al lugar de los hechos para comprobar la muerte. Tanto en Centroeuropa como en Francia e Inglaterra se conoce la misma conducta por diferentes normativas. Sólo un agente judicial podía descolgar el cadáver de un suicida ahorcado, para garantizar, entre otras cosas, que la comunidad no sufriese ninguna desgracia ${ }^{89}$. De tal manera, la casa, como escenario frecuente de suicidio, estaba sometida a una serie de rituales y supersticiones que se extendían a la propia extracción del cuerpo del difunto. Por eso, no se puede proceder de un modo convencional, sino a través de un pasadizo excavado por debajo del umbral de la puerta principal de la casa; aunque otras fuentes indican que también podía realizarse este mismo procedimiento por una ventana o a través de un agujero practicado en un muro. Así aparece recogido en la zona alemana - en los estautos de Goslar (mediados del s. XIV), en las costumbres de Rügen (1525-1531) o en diferentes crónicas (Frankfurt 1440, Metz, 1484)-. Estos ritos ancestrales tenían su origen en el mundo germánico y se extendieron en el siglo XV a zonas del Norte de Francia (1492, Libro Rojo de Abbeville) y de Suiza (1505), permaneciendo en sus leyes hasta el

85 "Capítulo catorce que dice et fabla de la remision de los homicidios casuales". Ed. Pablo ILARREGUI; Segundo LAPUERTA, Fuero General de Navarra. Amejoramiento del Rey don Phelipe. Amejoramiento de Carlos III, Pamplona, 1964, (Colecc. Derecho Foral, vol. I), pp. 282-283. Amejoramiento de Carlos III, de 1418. Lo mismo se indica en el siguiente texto, por el cual Teobaldo II eximía del pago de los homicidios casuales a los vecinos de Barasoain: Nos en remission de nuestros peccados quitamos por todos tiempos por nos et por nuestros successores que, - si ombre (a)negare en agoa, o si paret caye de suso, o si cayere de casa o de arbol et moriere, o si ombre tirasse piedra et non ueyendo matasse a otro, o si cayere de bestia et moriere, o si quemasse en fuego que (por) si mismo fuesse presso, o si quemasse de augua cayllient qui le cayesse por occasion et non por su grado, por quoal se quiera occasion d'estas obrenombradas-, que non paguen nunca homizidio a nos nin a nuestros succesores [nin eillos nin lures successores]. 3 de Septiembre de 1264.-Olite. Vid. Luis Javier FORTÚN PÉREZ DE CIRIZA, Colección de fueros menores de Navarra y otros privilegios locales (II), "Príncipe de Viana", 43, 166-167 (1982), doc. núm. 114, pp. 1022-1023.

${ }^{86}$ Vivanco recoge para Castilla algún caso de muertos en justas y torneos que fueron sepultados en cementerios o lugares no consagrados. L. VIVANCO, Death in fifteenth century
Castile, pp. 70-71.

${ }^{87}$ AGN, Comptos, Registros, 51, fols. 99-104 (faltan folios 100 v. a 103 r)., año 1344.

Publ. F. IDOATE, Catálogo de la Sección de Comptos. Registros, 51, n. 505 .

${ }^{88} \mathrm{~L}$. VIVANCO, Death in fifteenth century Castile, pp. 82-83 cita diferentes casos y disposiciones legislativas sobre el enterramiento en sagrado de delincuentes (ladrones) y criminales. En Las Partidas, no se prohibía la ihumación cristiana de los ladrones, siempre que hubiesen confesado previamente a su muerte o ejecución.

${ }^{89}$ G. MinoIs, History of Suicide, p. 39 y A. MurRay, The Curse on Self-Murder, p. 18. 
siglo $\mathrm{XVI}^{90}$. Pese a todo, ni en el territorio navarro ni en el resto de la Península se tiene constancia sobre tales prácticas. Sólo puede certificarse que también imperaba la costumbre de avisar a la autoridad judicial local, el merino, que decidiría el procedimiento a seguir. Lo más habitual era que el cuerpo permaneciera escoltado, hasta tres días, mientras se realizaba la investigación sobre el contexto del suicidio, tal y como indica el Fuero Reducido.

En las villas del rey, si un villano mata a otro, los vezinos deben trabar al homiçida y llevarlo al rey o a su Corte o a su merino, el qual si alli no se llevare repicando las campanas, los unos deben guardar el malhechor y los otros deben ir a buscar el merino, y renderlo dentro de tres dias, que de otra manera deberan el homiçidio, salvo si el homiçidio se hiço no sabiendo ellos, ansi como si de noche fuese muerto o se matare a si mismo, o por algun caso muriese ansi como por caida, o si el matador fuese infançon y no villano ${ }^{91}$.

Y lo demuestran otros documentos.

Item por loguero expens de hun ombre imbiado al dicho governador por razon que Gracia dIracheta enforco su cabeça: que queria que yo fizies del cuerpo, de sus bienes; et el dicho governador embiome dezir por su carta data sabbado postremero dabrill que rendies el dicho cuerpo et sus bienes a sus parientes por razon que era loca en IIII dias, que sovo el dicho ombre ata que ovies respuesta del dicho governador por loguero et expens VI sueldos. Letra Resuelta. Item expens de III ombres que cataron el dicho cuerpo de dia et de noches en los dichos IIII dias ata que ovies el dicho mandamiento, XII sueldos ${ }^{92}$.

\section{CONSECUENCIAS JURÍDICAS Y SOCIALES DEL SUICIDIO}

En el caso de que se determinara con seguridad que había acaecido un suicidio, se establecían diferentes categorías mediante las cuales se clasificaba a la víctima. Las Partidas componían varias causas que podían llegar a paliar el acto suicida y que permitían evitar la condena de homicidio. Interesa especialmente la tercera, que incluye la locura y la ira ${ }^{93}$. En este sentido,

${ }^{90} \mathrm{~J}$.-C. SCHMITT, Le suicide au Moyen Âge, p. 10. G. MinoIs, History of Suicide, pp. $35-$ 36. A. MURRAY, The Curse on Self-Murder, pp. 23-29.

${ }^{91}$ Libro VI, Tít. X, De los homicidios y muerte, y de los que dan veneno o se matan, Cap. 10, "En que lugar debe ser rendido el homiçidio que se debe." Véase Ismael SÁNCHEZ BELLA; Mercedes GALAN LORDA; Carmen SARALEGUI; Isabel OSTOLAZA, El Fuero reducido de Navarra: (edición crítica y estudios), Pamplona, 1989, p. 489.

${ }^{92} \mathrm{AGN}$, Comptos, Registros, 25, fol. 157 r., año 1329. Asimismo, el caso de Pedro Santofuego: ...Item per expenssam XII hominum qui custodiebat nocte et die Petrum Santofuego qui se suspendit usque scirent veritatem de morte eius in IIII.or diebus et noctibus pro qualibet die X solidos fit XL solidos. (AGN, Comptos, Registros, 13, fol. 189 r. y 189 v., año 1309).

${ }^{93}$ Partida 7 a , Tít. 27. Ley 1 , «Qué cosa es desesperación y de cuántos modos se cae en ella. Desesperamiento es cuando el hombre se desfinca, e se desampara de los bienes de este mundo e del otro, aborreciendo su vida e cobdiciando su muerte. Se incurre de cinco modos: primero, cuando alguno ha cometido grande delito y por temor o vergüenza de la pena se mata 
indica Ariel Guiance que la normativa hispánica era mucho más indulgente que las leyes europeas, pues las víctimas afectadas de locura o ira gozaban de capacidad sucesoria y no sufrían la confiscación de sus bienes al ser calificadas como "insanas" o "inconscientes" 94 . Igualmente, eran contempladas detalladamente otras causas como la enfermedad o el deshonor, que en las regiones ultrapirenaicas no eran tenidas en cuenta y que, sin embargo, en el mundo hispánico son importantísimas; fundamentalmente la cuestión del honor, tanto en el ámbito individual como en el familiar o social ${ }^{95}$. Esta preocupación también halló eco en la normativa foral y se percibe en la siguiente disposición legal, por la cual quedaba establecido que todo villano del rey que se suicidase debía ser excluído de la pena de homicidio:

En la villa del Rey si un villano del Rey matare a otro, los vezinos deven travar del homiziero et levar á la sied del Rey ante que passe tercer dia. (...) Et si ynfanzon lo matare, ó de nuyt lo matare, ó si él mismo se matare, ó si la cenia de la rueda que de fueras anda lo matare, los villanos del Rey porque el homiziero non prisieren por muerte de aquestas IIII cosas, por fuero homizidio non deven en la sied de Orqueyen, porque non rendieron. Et si bestia ó otro ganado, ó si en otra guisa lo mataren, prengan el homiziero ante que passe el terzero dia, et riendan con fermes en la sied del Rey. Et si esto non fizieren, en cuyo término moriere el ombre, los villanos del Rey el homizidio deven al Rey ${ }^{96}$.

La legislación navarra no era tan comprensiva como la castellana, sino que se aproximaba más a las normativas francesas y centroeuropeas, ya que, a todas luces, consideraba a los desesperados como homicidas y, por todo ello, plenamente culpables ${ }^{97}$. Pero sólo una ínfima parte de los suicidios navarros fueron estimados como fruto de la locura, frente a una inmensa

con sus manos o bebe yerbas con que muere. Segundo, cuando alguno se mata por gran dolor ocasionado por su enfermedad. Tercero, cuando alguno lo hace con locura o con ira. Cuarto, cuando un rico honrado y poderoso, viendo que le desheredan o deshonran, se desespera poniéndose a peligro de muerte o matándose. Quinto, es el de los asesinos y los otros traidores

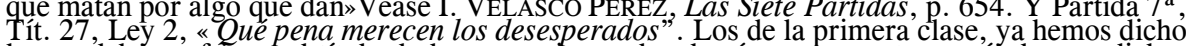
la que deben sufrir en el título de las acusaciones; los demás que se matan según hemos dicho, la que deben sufrir en el título de las acusaciones; los demás que se matan según hemos dicho, no den sufrir pena alguna; mas si matasen a otro sufrirán la que hemos dicho en el título de los homicidios.» E idem, p. 655. "Que pena merescen auer los desesperados". Aborrescen los homes mismos, assi como diximos en la ley ante desta: E de la pena que deuen auer estos atales fablamos en el titulo de las acusaciones, en la ley que comiença, desesperado seyendo. E los otros desesperados, que se matan ellos mismos por algunas de las razones, que diximos en la ley ante desta, non deuen auer pena ninguna (...)». En G. LÓPEZ (glos.), Las Siete Partidas del Sabio Rey Don Alonso, vol. III.

${ }^{94}$ A. GUIANCE, Los discursos sobre la muerte, pp. 368

${ }^{95}$ Idem, pp. 367-369 y 376-377. Sobre la deshonra como causa de suicidio mencionada en Las Partidas, Vease Rafael SERRA RUIZ, Honor, honra e injuria en el Derecho medieval español, Murcia, 1969, p. 237.

${ }^{96}$ FGN, Libro V, Título IV: De Homizidios. Capítulo XXI: “En qué logar y en qué manera se deve render el homizidio". Ed. de P. ILARREGUI; S. LAPUERTA, Fuero General de Navarra, p. 191 .

${ }^{97}$ «...desesperada de la gracia et misericordia de nuestro seynor Dios indubto del diablo que a seydo su conseillo et ministro se es de eill mesmo enforcado et dapnado por la quoal cosa segunt fuero, uso et costumbre de nostro regno et seynoria todos sus bienes muebles inmuebles do que [borrado] faillen son aplicados et confiscados a la corona...» (AGN, Comptos, Documentos, caj. 61 , n. 57, VIII, 28 de Julio de 1391.-Pamplona). 
mayoría que fueron condenados como actos de desesperación $n^{98}$. Desesperación que fue clasificada, al igual que en el caso francés, dentro de la categoría de "propósito deliberado" ". Todo ello indica una poderosa influencia de los usos franceses en las leyes navarras ${ }^{100}$, sin duda ejercida por la eficaz maquinaria fiscal y judicial del reino que persigue el delito hasta sus últimas consecuencias imponiendo penas muy rigurosas ${ }^{101}$. En ese caso, esta muerte es valorada como un homicidio, con las pertinentes consecuencias legales y espirituales para el fallecido.

Volviendo al asunto de la desesperación cabe señalar que en la Edad Media no se consideró como un estado de ánimo, sino como un vicio, por lo tanto un pecado inducido por el diablo, quien provocaba la duda sobre la misericordia de Dios respecto a su poder salvador. De tal modo, la desesperanza era concebida como la causa más inmediata de suicidio, un triunfo del diablo, que había logrado que un ser humano perdiera totalmente su fe en el Creador. Suponía, por tanto, una victoria de las fuerzas del mal que perturbaban el orden establecido en la naturaleza ${ }^{102}$. Así pues, la Desesperatio se enfrentaba directamente a la Spes en una batalla que finalmente ganaba la primera. Paralelamente podía presentarse, además, otro combate entre Ira y Patientia en la que esta última era derrotada. Ira y Desesperación eran los dos motivos fundamentales de suicidio, pero existía otra serie de vicios, tales como Accidia o Tristitia que conformaban un entramado muy complejo y que conducían a la desesperación como móvil final de suicidio. Esta lucha metafórica entre vicios y virtudes está basada en la que describe Prudencio en su Psychomachia y es tan clara y explícita que la Iglesia se inspiró en estas teorías para componer su aparato doctrinal en torno a esta cuestión. La iconografía religiosa para los manuales de confesores así como los programas escultóricos y pictóricos de los edificios religiosos tomarán su base en esta obra, componiendo un esquema visual de corte didáctico para los fieles.

Además, aparecen categorizadas en numerosos relatos literarios tales como exempla de sermones, narraciones milagrosas o vidas de santos, dando lugar a un marco de influencia de enorme difusión por todo el Occidente

\footnotetext{
${ }^{98}$ Los locos suponen un $9 \%$ (3 casos), frente a un $48 \%$ (16) que fueron considerados como desesperados. Cantidades, como se puede ver, claramente descompensadas. Casi en un $44 \%$ de los casos (7 referencias) la desesperación se asocia con la tentación diabólica o la inducción del diablo. Algunos ejemplos de ello son los que se siguen. ... por instigacion del diablo et como desesperado eill. . (AGN, Comptos, Documentos, caj. 75, n. 54,15 de Julio de 1397.-París, suicidio de Lope Îñiguez, vecino de Villava). En otras noticias, algunos personajes son definidos como desesperados en un documento y en otro como tentados por el diablo, como ocurre con Jamilla, judia de Sangüesa: ... por razon que desesperada de la gracia et misericordia de Dios... (AGN, Comptos, Registros, 258 , fol. $230 \mathrm{r}$., año 1400) frente a ... por instigacion del diablo et desesperada de la missericordia de Dios... (AGN, Comptos, Documentos, caj. 85, n. 30, 14 de Mayo de 1400.-Olite).

${ }^{99}$ J.-C. SCHMiTT, Le suicide au Moyen Âge, p. 8 «suicides de certain propos» y pp. 14-16.

${ }^{100} \mathrm{La}$ legislación del reino no indica ninguna noticia al respecto, por lo que estas conclusiones han sido obtenidas exclusivamente a partir de la aplicación práctica de la misma en los documentos de Comptos, como se ha visto en diversos ejemplos documentales.

${ }^{101}$ Influencia, sin duda, establecida por el aparato administrativo que introdujeron en Navarra los reyes de la dinastía Champaña en 1234. 33.

${ }^{102} \mathrm{~J} .-\mathrm{C}$. SCHMITT, Le suicide au Moyen Âge, pp. 4-5. Y G. MinoIs, History of Suicide, p.
} 
medieval, que pugna por desarrollar la idea de confianza en la Providencia y en el desarrollo de la fe por la vía doctrinal. Junto a todo ello, este programa se completará con un refuerzo del papel de la confesión ${ }^{103}$, que conllevaba el perdón de los pecados del feligrés y con ello la eliminación de cualquier motivo de desesperación. Por todo ello, una vez que la Iglesia hubo delimitado y fomentado un programa de prevención y actuación "personalizada" para evitar la lacra del suicidio no dudó en ningún momento de la efectividad del método: ningún buen fiel cristiano podría considerar esta opción de forma "racional", por lo que, cuando acontecían suicidios entre parroquianos de conducta intachable y de honradez probada, la causa que se buscaba a estas muertes era una tentación diabólica o la locura ${ }^{104}$.

La locura no era originada por un factor único sino que podía estar causada por diversas circunstancias. Una de ellas era el excesivo sufrimiento moral y físico - contemplado por Las Partidas, como ya se ha explicadoque acarreaba la propia existencia. Esto podría llevar encadenado una progresiva aversión por la vida que podía llegar a provocar el deseo de suicidio $^{105}$. Esta apatía podía asociarse o derivar en melancolía (melancholia - denominada así por Bruneto Latini en 1265 y asociada a una afilicción psíquica debida a un exceso de bilis negra que empañaba el cerebro y empujaba a pensamientos sombríos-), otro síntoma de locura en esta época $^{106}$. A la melancolía se oponía el frenesí, manifestación totalmente opuesta. Mientras que la primera se declara a partir de gestos introspectivos y es más difícil de detectar, el frenesí es mucho más conocido por sus ataques violentos, alucinaciones y delirios; era tan aceptado generalmente que poco se podía hacer contra él. Sin embargo, la apatía ante la vida es calificada más duramente por algunos tratadistas como síntoma manifiesto de locura, pues el hombre medieval, tiene un sentido religioso y trascendente muy marcado por su fe y no duda de que la existencia, y concretamente la propia, forman parte de la voluntad divina. Por tanto, todo aquel que se opusiera a tal voluntad y a su propia vida estaría obrando contra el orden natural. De tal modo, o bien estaría sometido a influencia de las fuerzas del mal -en primer lugar y lo más probable para la mayoría de la población - o al influjo de la locura -en caso de dementes manifiestos y religiosos que, debido a sus conocimientos religiosos y culturales, estaban más advertidos contra ellas- como se ha manifestado igualmente al tratar el tema de la desesperación.

\footnotetext{
${ }^{103}$ G. MiNOIS, History of Suicide, pp. 14-17.

${ }^{104}$ Idem, p. 34.

${ }^{105}$ Dice Minois que la mayor parte de los suicidios podrían haber sido originados por las tribulaciones y sufrimientos de la vida, eligiendo esta vía como solución a los mismos (hambre enfermedad, indulgencia, desamor, extrema pobreza, encarcelamiento y miedo de tortura judicial $\mathrm{o}$ bien celos). Así pues, esta aversión por la vida y sus circunstancias puede ser catalogada como locura. Idem, p. 38.

${ }^{106}$ Sobre la melancolía y el sentimiento melancólico provocado por la doctrina eclesiástica en torno a la cuestión del memento mori, Véase el interesante estudio de William E. ENGEL, Mapping mortality. The persistence of memory and melancholy in early Modern England, Massachusetts, 1995 , pp. 54 a 66.
} 
El número de suicidas que fueron declarados víctimas de la locura en general resultaron muy inferiores a los que se clasificaron como desesperados tanto en Navarra como en Europa. Pero es especialmente reseñable que en Navarra las estadísticas son llamativamente bajas, frente a otros casos europeos $^{107}$, confirmando mejor, si cabe, el poder del sistema jurídico en Navarra que castigaba el suicidio a todos los niveles posibles; sobre todo cuando era considerado como acto desesperado, como se verá a continuación.

La primera medida legal que se tomaba contra el suicida era el embargo de sus bienes ${ }^{108}$. Este procedimiento ya había sido practicado en el Imperio romano, cuando las pertenencias de los suicidas recaían en la persona del emperador, máximo representante del Estado. Posteriormente derivó a los pueblos bárbaros, que consideraron estas propiedades como patrimonio público y era custodiado, a su vez, por el rey, figura suprema dentro de su organigrama sociopolítico. Esta fue la postura que persistió en la primera Edad Media ${ }^{109}$, al mismo tiempo que se desarrolló el feudalismo, por el cual el concepto de "posesión”, englobaría a las personas (sus cuerpos y propiedades materiales incluídos) dentro de una compleja red de obligaciones. En estos momentos el poder de un señor no se medía tanto por la extensión de las tierras de las que disfrutaba como por el número de personas que las habitaban. Este tipo de relaciones puede aplicarse al cuerpo, especialmente en el caso de un suicida, de tal modo que sobre su cadáver tenía propiedad su señor y, por tanto, total derecho a imponerle sanciones. Esta identificación del cuerpo con un bien material tiene suma importancia a la hora de comprender los embargos de bienes a suicidas que se practicaron habitualmente en toda Europa a lo largo de la etapa medieval ${ }^{110}$.

Un buen ejemplo de ello puede verse en el siguiente documento, por el cual se confiscan los bienes al vecino de Olite, Lope de Olleta.

(fol. 24 r.)

A la vuestra real magestat. (Con estampilla: Año 1414)

El vuestro humil Johan Miguel dEchauri portero vuestro me comiendo en

la vuestra gracia et merçe muyt alto seynnor reçebi una vuestra carta de mandamiento la quial es segunt se sigue. Karlos por la gracia de Dios rey de Nauarra, duc de Nemours a quoal quiere official o portero de nuestro

\footnotetext{
${ }^{107}$ Un $9 \%$ del total, frente a un 30\% de los casos de J.-C. Schmitt (16 de 54), o 4 de 5 de los que el propio Minois estudió a partir de los Registros de Saint-Martin-des-Champs: 4 suicidios en los que se anotaban las siguientes expresiones «furioso y sin sus sentidos», «loco y fuera de sus en los que se anotaban las siguientes expresiones «fur
sentidos» 0 «desvariando y fuera de sus sentidos».

${ }^{108}$ En el siglo XIII, Philippe de Beaumanoir aconsejaba que no se procediese a la confiscación de los bienes del suicida hasta que no se demostrase claramente si se había dado muerte con intención manifiesta. Y en el XIV, Jean de Boutillier indicaba que, cuando se hubiera producido una muerte por suicidio, no se debía imponer ninguna pena a la víctima. G. MiNOIS, History of Suicide, pp. 39-40.

${ }^{109}$ La aplicación de esta medida data del siglo IV cuando Constantino, estableció que los bienes pertenecientes a un suicida que se había dado muerte por remordimiento tras haber cometido un crimen pasasen a manos del Estado en el acto. Si el suicidio había sido causado por cansancio ante la vida deudas o enfermedad, se respetaban las propiedades. G. MINOIS, History of Suicide, $\mathrm{p}$ 29. Y Ȧ. MURRAY, The Curse on Self-Murder, p. 64, donde indica que la palabra "confiscación"; deriva del latín fiscus que alude al tesoro del Emperador romano.

${ }^{110} \mathrm{~A}$. MurRAY, The Curse on Self-Murder, pp. 55-56.
} 
regno salut. A nuestra noticia es venido que agora pocos dias ha Lope dOilleta, vezino de Olit por temtacion diaboliqua al ha enforcado su cabeça por la quoal cosa es dapnado et todos sus bienes muebles et heredaminetos son confiscados et aplicados et pertenescen a nos por esto vos mandamos firmement que luego vistas las presentes quoalquiere de vos que requerido seades et mandado vos sera por nuestro amado et fiel procurados fiscal Lope Lopiz de Bearin pongades a execucion et uendida publicament a publiquos pregones todos et quoalesquiere bienes muebles et heredamientos que faillar o saber podieres ser del dicho Lope de Olleta et al mas dant los y firmedes si quiere... (...) Datum en Puent de la Reyna so nuestro siello de la chançeleriia .IIII $^{\circ}$. dia de deziembre layno del nascimiento de nuestro seynnor de mil CCCC.os. et doze por el rey...

(fol. $31 \mathrm{r}$.)

(...) Item al notario por fazer el inuentario por fazer las vendiçiones de los bienes mobles, XL sueldos ${ }^{111}$.

A todo esto viene a sumarse otra cuestión, la asociación de determinados objetos físicos a personas, de modo que se identificaban plena e indisolublemente unos con otros, así, un guerrero es asociado a su espada y sus ropajes y ambos le acompañarían a su tumba. Por tanto, a un hombre bueno se le respetaría la propiedad, símbolo de su identidad, frente a un hombre malo (un suicida manifiesto, un delincuente o un criminal) al cual le sería embargaría para acentuar aún más el deshonor de su comportamiento ${ }^{112}$; llegando a manos del rey, máxima autoridad y depositario del patrimonio público, del cual puede disponer para procurar el bien de la comunidad.

En la plena Edad Media, son numerosos los reglamentos europeos que formalizan la confiscación ante un caso de suicidio, aunque las causas fueran debidas a diferentes concepciones ${ }^{113}$. Por un lado, el continente recoge el legado del Derecho Romano lo que influye en el concepto de jerarquía que poseían estos territorios. De tal forma, la máxima autoridad central estaba revestida de un poder cuasi-sagrado, herencia del mundo romano que llegaba hasta los más pequeños ámbitos de poder jurisdiccional. Todo ello devenía en que la práctica de la confiscación aplicada a suicidas únicamente era detentada por el rey, mientras que los restantes señores, vasallos del monarca, no podían ejercerla, porque para todos ellos el suicidio sólo revestía carácter de ofensa, no de crimen ${ }^{14}$. Por otro lado, en las Islas Británicas no se recibió la influencia del código romano y el suicidio fue considerado, a diferencia del resto de Europa, como un acto de felonía, esto es, una ofensa especial contra la Corona. Por lo cual el rey era el único con derecho a perseguirla y determinar las medidas que se debían tomar para lo que se procedía de una manera diferente a lo visto en el continente, basada en dos puntos: la identificación del crimen y la aprehensión del criminal ${ }^{115}$. En ambos casos, las

\footnotetext{
${ }^{111}$ AGN, Comptos, Documentos, caj. 114, n. 8, fol. 24 r.-34 r., 4 de Diciembre de 1412. A partir del folio 25 , se encuentra el inventario de los bienes embargados.

${ }^{112}$ A. Murray, The Curse on Self-Murder, pp. 56-57.

${ }^{113}$ L. VIVANCO, Death in fifteenth century Castile, pp. 87-88.

${ }^{114}$ A. MurRay, The Curse on Self-Murder, p. 66.

${ }^{115}$ Idem, pp. 67-68.
} 
consecuencias legales, sin embargo, eran semejantes, y confluían en la confiscación de las propiedades del suicida como castigo por el pecado cometido, que alteraba el orden natural de la sociedad.

En Francia la primera actuación legal conocida está fechada en 1205 y por ella los bienes confiscados a un suicida fueron asignados al rey o a un barón. Patrones similares siguieron otras leyes que se prolongaban hasta el siglo XIV. En Inglaterra existieron igualmente normativas muy similares que seguían estos mismos esquemas, como la datada en 1230 en Surrey ${ }^{16}$. Mientras que en Castilla, según Las Partidas sólo se procedía a la confiscación de las propiedades si el difunto había cometido con anterioridad algún crimen, lo que se extendía no sólo al suicida, sino también a otros difuntos. No obstante, las Ordenanzas reales de Díaz Montalvo, datadas a finales del siglo XV, sí aplicaban esta pena a los suicidas, si bien únicamente en el caso de que no tuviesen herederos descendientes ${ }^{117}$.

En Navarra, al igual que en los reinos mencionados, también se efectuaba esta práctica por la que las propiedades embargadas pasaban a manos del rey, que generalmente las destinaba a la venta a través de subasta pública ${ }^{118}$.

De Thoda, muger de Pero Felip, vezina de Lonbier, los heredamientos de la quoal fueron confiscados al seynnor rey por razon que eilla mesma, desesperada de la gracia de Dios, se enforquo et aqueillos bienes vendidos publicament a pregon por Miguel dOstiz, portero, montaron abatidas las expenssas segunt peresce por relacion del dicho portero XXV florines al dicho precio valen XXXII libras X sueldos. Item de los bienes muebles vendidos por el dicho portero X libras III dineros que montan XLII libras $\mathrm{X}$ sueldos III dineros ${ }^{119}$.

En otras ocasiones el rey las donaba a miembros de su corte y a servidores de sus hostales ${ }^{120}$, como lo indican numerosos documentos.

De Johan Yniguiz, mulatero, vezino de Mont Real, el quoal, desesperado de la gracia de Dios, eill mesmo se enforquo et por esto todos sus bienes confiscados el seynnor rey. El dicho seynnor rey aqueillos ha dado de dono a Pere Campaynna, valet de la panneria para eill et sus suçessores a perpetuo como peresçe por su letra. Datum $\mathrm{XI}^{\circ}$ dia de Agosto nonagesimo VI. Por aquesto aqui, nichil ${ }^{121}$.

\footnotetext{
${ }^{116} \mathrm{G}$. MiNOIS, History of Suicide, pp. 36-37.

${ }^{117}$ L. VIVANCO, Death in fifteenth century Castile, p. 88.

${ }_{118}$ «De Domenga de Gascue, moradera en Guendulayn, cabo Ripa, la quoal por razon que faillaron enforcada et eilla mesma se dapno, pertenesçian todos sus bienes al seynor rey et puestos su mano por Garcia dOlaz, portero, como peresçe por el inventario. Et enpues vendidos publicament por el dicho portero valieron como peresce por su relaçion VII libras V sueldos». (AGN, Comptos, Registros, 217, fol. 267 r., año 1392).

${ }^{119}$ AGN, Comptos, Registros, 229, fol. 460r, año 1395. Otro ejemplo: En Guerguetiaynn de Pero Ayuar, que se enforco avll mesmo por su part de los muebles vendidos IIII libras X sueldos. (AGN, Comptos, Registros, 10, fol. 69 v., año 1306).

${ }^{120} \mathrm{La}$ misma costumbre se observa a finales del siglo XIV en la corte del rey Ricardo II de Inglaterra. G. MINOIS, History of Suicide, p. 37.

${ }^{121}$ AGN, Comptos, Registros, 231, fol. 256 r., 11 de Agosto de 1396.
} 
Por otra parte, en el caso de que se confirmase que una persona se había dado muerte debido a una demencia, a un estado de locura, esta cuestión era considerada como eximente lo cual permitiría la devolución de los bienes a sus familiares ${ }^{122}$ y una cierta exculpación social del acto. Actitud comprensiva que favorecía a las gentes más cercanas al difunto y no comprometía a la familia afectada evitando su repudio social ${ }^{123}$. Igualmente en Inglaterra, la compilación De legibus et consuetudinibus Angliae (1250-1260), establecía un tratamiento de los bienes del suicida en función del tipo de acto cometido. Así, los considerados non compos mentis no sufrirían el embargo de bienes, mientras que los que eran calificados como felo de se, experimentaban la pérdida de tierras y pertenencias ${ }^{124}$.

Ibi, de las heredades que fueron de Xemeno dona Elpha, puestas a mano de la seynoría por razón que el dicho Xemeno se enforcó en la eglesia... nichil, que a suplication de Johan Xemeniz et de Domenga, hermanos del dicho Xemeno, fue fecha pesquisa, en la quoal fue faillado que ante que la dicha ocasion le contesciesse et al tiempo era loco et fuera de entendimiento, et por tanto el seynnor rey mando que las dichas heredades fuessen rendidas a los dichos sus hermanos ${ }^{125}$.

En circunstancias especiales, se procedía a la devolución de una parte de los bienes a los familiares. Como en este ejemplo que se incluye a continuación en el cual la mitad de las propiedades de la suicida eran donadas a sus cinco hijos.

Karlos por la gracia de Dios rey de Navarra conte dEvreux. A nostro bien amado et fiel procurador Johan Karitat et Garcia Miguel substituydo por vos en la villa de la Puent de la Reyna a goardar nostros derechos. Salut. Como el XXIX ${ }^{\circ}$ dia del mes de Agosto que postremerament passo Gracia Martiniz de Blascoayn muger que fue de Garcia Periz de Açança, ferrero, morant en la dicta villa de la Puent, temptada por el diablo o eilla sabia por que, se dize saillio de casa casi a media noche et se echo en la agoa do depues fue faillada afogada. Por la quoal cosa los pocos bienes muebles que avian los dictos marido et muger fueron puestos luego por inventario a nostra mano por vos dicho Garcia Miguel substituydo de nostro procurador et estan encara embargado como bienes qonfiscados a nos a lo menos la

\footnotetext{
${ }^{122} \mathrm{Se}$ ha hablado con anterioridad que la locura, de la misma manera, era considerada eximente de culpa que permitía el entierro en sagrado.

${ }^{123}$ La familia era considerada culpable por no haber puesto los medios necesarios para evitar el suicidio. Por ello, tenía una parte de responsabilidad en el acto, y debía expiar públicamente su culpa con su deshonra. Ya se documentaba en el Antiguo Testamento y pasó al Imperio responder por los delitos y crímenes cometidos por un familiar. A. MURRAY, The Curse on SelfMurder, p. 17.

${ }^{124} \mathrm{G}$. MINOIS, History of Suicide, pp. 36 y 37. Efectivamente, una de las consecuencias de un suicidio era que el castigo se ampliaba a los parientes, y amigos del fallecido, a través del despojamiento de los bienes materiales y del deshonor público de la familia que se manifestaba con la exclusión social de todos ellos, obligados a soportar el escarnio público del suicida. As lo afirma también J.-C. SCHMITT, Le suicide au Moyen Age, p. 11.

${ }^{125} \mathrm{AGN}$, Comptos, Registros, 115, fol. 4, año 1365.
} 
part et meatat pertenescient a la dicta Gracia Martinis qui fue. Et agora sea venido a nos el dicto Garcia Periz, marido de la dicta Gracia, con cinquo criaturas que ensemble avian chiquos et de menor hedat son a saber Michelco, Johaneta, Johancha, Martico et Simonet et nos ayan suplicado et pidido por merce que en esgoart de almosna quisisessemos dar a las dictas criaturas por criar la part et meatat de los dictos bienes de la dicta su madre que fue la quoal meatat puede valer X. libras poco mas o menos. Nos inclinado a su humil supplicacion, movido de piedat enta las dictas criaturas lis avemos dado et damos por las presentes en almosna et por amor de Dios la dicta part et meatat de los dictos bienes muebles pertenescient a la dicta Gracia Martiniz lur madre que fue. Si vos mandamos et a cada uno de vos segunt pertenesce que la part et meatat de los dictos bienes pertenescient al dicto Garcia Periz et bien assi la otra meatat pertenescient a la dicta Gracia Martiniz que fue la quoal nos avemos dado a sus dichas criaturas como dicto es vos lis relacxedes et desembarguedes o fagades relacxar et desmbargar luego et sin detenimiento alguno por fazer a lur propria voluntat car assi lo queremos et nos plaze. Et a nostros amados et fieles las gentes oydores de nostros comptos et thesorero qui es o sera mandamos que de los dictos bienes por nos dados en almosna como dicto es vos tengan por quoantos et por descargados et vos los reciban et passen en vestres comptos por testimonio destas present tan solament sin alguna defficultat. Datum en Estella so nostro sieillo de la cort XIII ${ }^{\circ}$ dia de Septiembre laynno de gracia mil .CCCos. nouanta et seys ${ }^{126}$.

En otras ocasiones los familiares luchaban para que un suicidio declarado fuese valorado como un acto de locura o una muerte accidental, y así evitar el embargo de los bienes y las consecuencias del castigo jurídico.

De Cathelina, muger de Garcia Martiniz de Arraiça qui fue et de Martin su fijo. El quoal dicho Garçia Martiniz fue faillado muerto et afogado en el rio de Arga cerqua la villa de la Puent de la Reyna. Et algunas gentes querian dizir que eill se auia ychado desesperado ad afogar et otros dizian que en las grandes crescidas de las agoas que entonz fazia lo abrian tomado. Et sobre esto el dicho procurador puso a mano de la seynnoria los bienes del dicho Garçia Martiniz. Et la dicha Cathelina, et el dicho Martin su fijo et otros parientes por no pleitear con el dicho procurador toastaron con el que ouiessen a pagar II.c. libras. Et el dicho procurador asi fecha la conpusicion con sabiduria de la seynnoria concludio con eillas que ouiessen a pagar las dichas II.c. libras. Et por que el dicho procurador las ha cobradas por esto aqui cargado eill en recepta II.c. libras ${ }^{127}$.

En muchos casos el suicida - principalmente si era un delincuente que había cometido este fatal acto para librarse de una sentencia judicial- era sometido, además, a ajusticiamiento y vejación, siendo su cuerpo arrastrado

\footnotetext{
${ }^{126}$ AGN, Comptos, Documentos, caj 72, n. 4, XVIII, 13 de Septiembre de 1396.-Estella. En el caso de Miguel Luengo, vecino de Falces, se devuelven los bienes e inmuebles del difunto incautados a cambio de que su hija pague una sanción de 20 florines. (AGN, Comptos, Documentos, caj. 113, n. 91, V. 10 de Diciembre de 1414.-Pamplona).

${ }^{127}$ AGN, Comptos, Registros, 399, fol. 368-374, año 1430.
} 
y posteriormente ahorcado como castigo ejemplar ${ }^{128}$. Como ocurrió en el caso de Miguel de Autol.

\begin{abstract}
Justizias feytas.(...) Otrossi que le significaua que eyll a present non tenia ninguno preso et otrossi que le significaua que Bleso Peris baylle de Çintrueynnego, tenia preso se tayllo la gola de que era muerto. Por que le madaua que si asi era vistas las presentes el cuerpo del dicho Miguel publicament rastrar et enforcar fiziese segunt que peresce por el dicho mando, el quoal fue dado en Olit XIX ${ }^{\circ}$ dia de Março anno Domini XLIIII $^{\circ}$. Et el dicho tenient logar de merino queriendo ser obedient al dicho mando si fizo rastrar et enforcar el cuerpo del dicho Miguel et costo el sayon qui lo enforco V sueldos et III dineros por el dogal. Summa per $\mathrm{se}^{129}$.
\end{abstract}

No obstante, gran número de juristas creyeron firmemente en la inutilidad de estas prácticas considerándolas viles y primitivas. En un esfuerzo por hacer prevalecer la razón y la fe, explicaban que las torturas no respondían al ideal cristiano, ya que el castigo a los suicidas debía provenir directamente del Creador, que juzgaría a estos hombres por medio de un juicio personal y justo ${ }^{130}$. San Agustín incluso llegaba más allá cuando determinaba que no se debía someter a los cadáveres de los suicidas a prácticas ultrajantes que mancillasen su dignidad y su condición humana, ni tampoco arrojarlos como si fuesen despojos a ningún lugar con objeto de castigarlos públicamente, para lo cual apelaba a que uno de los preceptos cristianos de la caridad consistía en dar sepultura a los difuntos ${ }^{131}$.

Estas costumbres no parecían tener demasiada difusión en Inglaterra —donde está prohibido por la justicia real—, ni en Italia — donde parecía que se producía excepcionalmente en el medio rural-; pero en cambio sí que tuvieron repercusión en Alemania y en Francia, especialmente en la zona Norte - mientras que la zona Sur recibía el influjo de las ciudades italianas-, donde, después de ser arrastrado por caballos (sobre una reja en Abbeville, 1492), el suicida era ahorcado ${ }^{132}$. En Navarra fueron muy habituales las penas

${ }^{128}$ G. MinOIS, History of Suicide, p. 35 hace referencia a la Ley de Beaumont, por la cual el castigo debía ser lo más cruel posible para demostrar la experiencia a la comunidad. Y en la p. 36 explica que estas puniciones servirian asimismo como rito de exorcismo - ya que este modo de muerte estaba asimiliada al demonio- al mismo tiempo que como ejemplo disuasorio para que estos actos no se repitieran.

${ }^{129}$ AGN, Comptos, Registros, 51, fol. 24 r., año 1344. Suicidio de Miguel de Autol.

${ }^{130}$ A. MURRAY, The Curse on Self-Murder, pp. 11-12.

${ }^{131}$ Recaredo FERNÁNDEZ DE VELASCO, Naturaleza jurídica de cementerios y sepulturas. Historia y problemas jurídicos, Madrid, 1935, p. 85.

${ }^{132}$ Sin embargo, en Alemania era más habitual que, después del arrastramiento del cuerpo, se procediera a la quema del mismo en lugar de recurrir al ahorcamiento. Así lo indican los estatutos de Goslar (mitades s. XIV). También se practica en ciudades como Frankfurt, Main o Nuremberg (s. XV). En la España del XVI, es frecuente la costumbre de ahorcar los cuerpos después de ser paseados por la ciudad, a pesar de que estos procedimientos eran condenados por leyes y juristas. A. MURRAY, The Curse on Self-Murder, pp. 32-35. J.-C. SCHMITT, Le suicide au Moyen Age, pp. 11-12, y G. MiNoIs, History of Suicide, pp. 35-37 donde también se describen los diferentes tipos de castigos infligidos a los suicidas. 
más duras, por las cuales los cuerpos de suicidas y criminales eran nuevamente ahorcados en público después de que su cuerpo hubiera sido arrastrado ${ }^{133}$ :

Aunque en algunos lugares de Centroeuropa la hoguera fue una práctica habitual para las mujeres suicidas - frente a los cadáveres de hombres, que, como ya hemos visto, eran sometidos a ahorcamiento- como lo indican algunas leyes ${ }^{134}$, en Navarra, los casos registrados parecen ser bastante excepcionales y reservados para la brujería y los judaizantes. En este ejemplo que sigue se procede así con un suicida judío, al que se somete a este tipo de ajusticiamiento. Cabe preguntarse si esta actuación se debió a la asociación de su condición de judío y de su acto suicida ${ }^{135}$.

(fol. 282r.) Juçe Embolat, fijo de mose Embolat, judio de los Arquos, morador en Esteylla que se forquo eyll mesmo en la casa del dicho su padre en la juderia dEsteylla. Et fue mandado por el noble don Guillem de Brae gobernador qui por tiempo fue en Navarra por cierta carta de mandamiento fecho al dicho baylle que eyll que fizies fazer justiçia del dicho Juçe Embolat es asaber que fues quemado sacando si algun judio su parient quesies dar algo por que non fues quemado el dicho cuerpo, a reçebido el dicho baylle del dicho mose Embolat por que non fuese quemado el dicho cuerpo XX libras...

(fol. 282v.) Cartas tornadas, nichil que el reçebidor las reçebia de iuras redemidas et de garançes nichil que non y fueron. Summa de toda la recepta de la dicha bayllia deste aynno XXII libras X sueldos. Expendio dineros (tachado todo lo que sigue) por expensa comun. Todo primero a seys ombres que sacaron el cuerpo de Juçe Embolat enforcado por si mesmo pora levar el dicho cuerpo a enterrar et a quemar et fue levado al pie de la forca et puesto en la estaca pora quemar pago XVIII.en dineros que montan IX sueldos ${ }^{136}$.

\footnotetext{
${ }^{133}$ Varios ejemplos de ello pueden encontrarse en las expensas por ajusticiamientos a homicidas que aparecen en los Registros de Comptos. «Espensa por fazer iusticia. (...) Item rastrer et enforquar a Xemeno de Villafranca porque mato a Pidruelo de Villafranca, su sobrino, yendo con el en conpannia. Por iuyzio del alcalde costo de levar lescallera a la forca et de adoçirla VI dineros, qui toco lanafil IIII dineros, la bestia que lo levo rasgando III sueldos, las cuerdas que fueron conpradas pora ligar la bestia et a sus piedes VI dineros, costo el dogal IIII dineros, los omes que fueron comigo $\mathrm{V}$ sueldos. Item enforquar e Ferrando dEstella por mandamiento del governador por razon que era ladron manifiesto que avie feyto muytos furtos et quebranto la persona del rey costo de levar lescalera et de adozir de la forca VI dineros qui tocava lanafil IIII dineros, el dogal IIII dineros, los omes qui fueron comigo,. $\mathrm{V}^{\mathrm{o}}$. sueldos. Item rastre et enforque a Lopo Mora de Ablites por mandamiento dol covernador por que avie degollado entorque a Lopo Mora de Ablitas por mandamiento del governador por que avie degollado a Ybraym dAlgabay en su alboleca et lo avie soterrado. Costo de levar lescalera a la forca et de adozir VI dineros qui toco lanafil IIII dineros, la bestia que lo levo rastrando III sueldos las cuerdas que fueron conpradas pora ligar la bestia et a sus piedes VI dineros, el dogal IIII dineros, los omes quie fueron comigo V sueldos» (AGN, Comptos, Registros, 19, fol. 3v.-4r., año 1344).

${ }^{134}$ Una ordenanza municipal de Lille (c. 1300) determina que el cuerpo de un suicida debe ser MINOIS, History of Suicide, p. 35 . También en las costumbres de Anjou o Bretaña, A. MURRAY The Curse on Sift-Murder p. 35. Tambien en las costumbres de Anjou o Bretana, A. MURRAY, caso en Douai (1398), por el cual una mujer que se ahorcó en su casa, fue quemada.

${ }^{135} \mathrm{~A}$ otro converso, acusado de judaizante, también se le quema en la hoguera. «In primis queme a Johan Ferrandez converso por juyzio porque era converso e andava por judio en e castiello de Tudela, que toco lanafil. IIII dineros, los omnes que fueron comigo V sueldos, costo vna cadena de fierro pora la çinta XII dineros, costaron cuerdas pora las manos y los piedes II ${ }^{136}$ AGN, Comptos, Registros, 49, fols. 282 r.-v., año 1343.
} 
En tercer lugar, se procedía a hacer efectiva la privación de sepultura eclesiástica ${ }^{137}$, aunque, en verdad, la mayoría de cuerpos a los que se denegaba el funeral cristiano usualmente recibían un "funeral civil ${ }^{138}$ ", sin ceremonia y fuera de suelo consagrado ${ }^{139}$. Es lo que en Francia se denominaba prophana sepultura y en Inglaterra se expresaba a través de las expresiones extra ecclessiastica sepelliatur o privation of burial. Santo Tomás de Aquino, por su parte, lo designó privabantur antiquitus honore sepulturae. Hasta aquí, la postura oficial de la Iglesia. Pero, en la práctica, los sacedotes otorgaban sepultura eclesiástica a los suicidas y les aplicaban los ritos habituales de intención, aunque fuesen reprobados por sus superiores. En cuanto a los monjes que se daban muerte, sus compañeros frailes rezaban por sus almas, a pesar de las prohibiciones que pesaban sobre ellos. También era posible la celebración de entierro en una parte del camposanto acondicionada para estos casos o bien en un cementerio construido ex professo para los suicidas ${ }^{140}$. Se supone, asimismo, que los terrenos adyacentes al cementerio, los campos que circundaban la ciudad y las proximidades de caminos también fueron espacios donde se procedía al enterramiento "extraeclesiástico" de suicidas, como lo afirmaba Pietro de Ubaldi $(\dagger 1420)^{141}$.

Es patente, pues, que la aplicación de las leyes no era siempre igual de rígida sino que se podían introducir algunos cambios o, incluso, podía producirse una ruptura de las mismas en función de una serie de razones más o menos arbitrarias ${ }^{142}$. La cuestión en sí es un tema espinoso porque las excusas que muchas veces se buscaban para realizar un entierro "anómalo" eran de lo más variopintas. Podían aducirse razones higiénicas, que en la mayor parte de los casos encubrían otros motivos. Lo que llevaba a que fueran

\footnotetext{
${ }^{137} \mathrm{~A}$ algụnos criminales sí se les celebraban funerales, aunque su cuerpo no fuera enterrado en suelo cristiano. Félix SEGURA URRA, Víctimas y agresoras: la mujer ante la justicia en Navarra durante la primera mitad del siglo XIV "V Congreso de Historia de Navarra, 10-12 Septiembre de 2002, Pamplona", Pamplona, 2002, vol. I veanse noticias en p. 150 y en notas 56 y 35. También Véase L. VIVANCO, Death in fifteenth century Castile, pp. 82-83. Ph. ARIÉS aseguraba que, en un principio, los cuerpos de los criminales sí podían ser sepultados en terreno consagrado. Pero durante la Baja Edad Media, la práctica pasó a ser muy diferente, siendo arrojados fuera del cementerio una vez condenados, El hombre ante la muerte, p. 45.

${ }^{138}$ Expresión acuñada por A. MURRAY en The Curse on Self-Murder, pp. 41-42 donde habla de «profane burial» y «non-burials» respectivamente. También en La grande mélancolie, p. 35.

${ }^{139}$ Parece que en Castilla existieron cementerios "civiles" donde se daba sepultura a los malhechores. L. VIVANCO, Death in fifteenth century Castile, p. 83.

${ }^{140} \mathrm{~A}$. MurRay, La grande mélancolie, p. 35. Y The Curse on Self-Murder, pp. 41-42.

${ }^{141}$ A. MurRaY, The Curse on Self-Murder, pp. 43-44. Los códigos de Rügen (1530) indican que un suicida debe ser enterrado, de acuerdo con el carácter del hecho, en un campo sin embrar.

${ }^{142}$ Conviene recordar una situación que recoge William SHAKESPEARE en Hamlet y que puede ilustrar muy claramente esta cuestión. Ofelia, desesperada ante la muerte de su padre, se arroja a la corriente de un río, muriendo. Eufemísticamente, su muerte es considerada en su entorno familiar como fruto de una caída accidental a la corriente. Por todo lo cual, las autoridades eclesiásticas permiten la celebración de unas exequias modestas, tras las cuales su cuerpo es eclesiasticas permiten la celebracion de unas exequias modestas, tras las cuales su cuerpo es
enterrado en cementerio, aunque sin sacramentos y sin ninguna bendición ni responso. Son especialmente significativos el diálogo de los sepultureros, que se contrapone al que mantienen el sacerdote oficiante y Laertes, hermano de la fallecida, mostrando dos posturas totalmente opuestas ante este asunto. Vid. cuarto acto, final de escena XXIV, y escenas I y III del quinto acto. Vid. William SHAKESPEARE, Hamlet, ed. de Manuel Angel CONEJERO (dir.), Madrid, 1997, pp. 593 y $595,599-603$ y 635-639.
} 
numerosos los suicidas que eran sepultados en suelo consagrado, incluído el interior de las iglesias - especialmente durante el siglo XIII $-{ }^{143}$. Cabe añadir que así como la locura era valorada como un atenuante a la hora de considerar la intencionalidad de un suicidio y el desembargo de las propiedades personales, también era tenida en cuenta a la hora de realizarse un enterramiento $^{144}$. De tal modo, el jurista Jean Boutillier (†1395) alegaba que, en los casos de suicidios por enfermedad o por locura (denominados forsennerie), los cadáveres eran inhumados según la pauta cristiana ${ }^{145}$.

Por todo ello, es muy interesante destacar que la prohibición de entierro tiene dos aspectos que los historiadores del Derecho canónico diferencian claramente. Por una parte, el funeral, entendido como celebración de oficios divinos, está íntegramente sometido a la autoridad total de la Iglesia. Los teólogos afirman, además, que ésta es la parte de ambas ceremonias que realmente importa, la que reporta beneficios para el alma en el Más Allá. En casos de disputa, éste es el apartado que la Iglesia realmente controla en su totalidad. Por otra parte, la sepultura en suelo consagrado es un asunto sobre el que la comunidad civil local puede ejercer una mayor influencia e imponerse a la autoridad eclesiástica. Para celebrarlo, pues, puede contar, o no, con la guía de la Iglesia, procediendo de tal manera, a un entierro cristiano o no religioso respectivamente ${ }^{146}$.

La primera formulación sobre este asunto se encuentra ya, en el ámbito hispánico, en el concilio de Braga en 561, por el cual además de la exclusión social del suicida, se prohibía su enterramiento en lugar sagrado. A nivel europeo este fenómeno vino a ser teorizado por diferentes canonistas varios siglos después, a partir del XII, y se plasmó por escrito en el Sínodo de Nimes (1284), donde se confirmó la negativa a sepultura cristiana ${ }^{147}$. En esta misma centuria Raimundo de Peñafort recogió una solicitud de exhumación de algunos cuerpos de suicidas inhumados erróneamente en cementerio. La legislación civil también se hizo eco, aunque en menor medida, de este dilema -en el siglo VII ya se aplicaba en Hertford (Inglaterra) donde estaban

\footnotetext{
${ }^{143}$ Las órdenes mendicantes y predicadoras se suman a la gran indignación de los sacerdotes de parroquias que, por el mismo asunto pierden los derechos de funerales y de sepultura. A MURRAY, La grande mélancolie, p. 17. Á. GUIANCE indica que muchos clérigos habian violado esta norma por ignorancia de la misma, Los discursos sobre la muerte, p. 361.

${ }^{144}$ Se puede recordar el caso de Gracia de Iracheta, cuyo cadáver es devuelto a sus familiares para que procedan a su entierro, al considerar que su suicidio había sido producto de la locura: "...por razon que Gracia dIracheta enforco su cabeça: que queria que yo fizies del cuerpo, de sus bienes; et el dicho governador embiome dezir por su carta data sabbado postremero dabrill que rendies el dicho cuerpo et sus bienes a sus parientes por razon que era loca...» (AGN, Comptos, Registros, 25, fol. 157 r., año 1329).

${ }^{145} \mathrm{G}$. MiNOIS, History of Suicide, p. 40.

${ }^{146}$ Idem, p. 42.

${ }^{147}$ Idem, pp. 34-35. Sin embargo, Joseph AVRIL arroja una fecha anterior, 1252, a partir del libro sinodal de Raimond Amaury en Nimes. Mort et sépulture dans les statuts synodaux du Midi de la France, Cahiers de Fanjeaux. 33. La mort et l'au-delà en France méridionale XIIIe-XVe siècle), Toulouse-Fanjeaux, 1998, p. 352. Por otra parte, A. MURRAY, The Curse on SelfMurder, pp. 182-183, indica que existe un concilio anterior, celebrado en Orleans (II), en el 533, por el cual se prohíben las oraciones por el alma de un suicida.
} 
prohibidos los ritos funerales cristianos para los casos de suicidio ${ }^{148}$ - , dando a entender claramente que era considerado un problema a resolver principalmente por la Iglesia.

En Navarra existen noticias que hacen pensar que sí se ofrece sepultura eclesiástica a algunas de las víctimas, aunque los paradigmas que determinan los diferentes casos no aparezcan definidos ni en la documentación de Comptos ni en la legislación. Por tanto, ante la falta de datos eclesiásticos relativos a este asunto, da la sensación de que fue la autoridad civil, principalmente la Corona, la que se encargó de regularlo. En caso de locura, cuando el sujeto no estaba en plenitud de juicio, se permitió su enterramiento en sagrado bajo los preceptos cristianos ${ }^{149}$. Pero cuando se determinó que el suicidio se había cometido bajo tentación diabólica o acto de desesperación, las ambigüedades se hacían presentes. De tal modo, en algunas ocasiones, el cuerpo era entregado a los familiares para que procediesen a su entierro en sagrado, aunque, posiblemente, no se celebrase ninguna ceremonia religiosa.

vos mandamos que el cuerpo de Johan Ruiz de Undiano, que agora poco tiempo ha por sus demeritos fue enforcado, et es caido en tierra, delibredes... a sus parientes secretament por lo enterrar en cimiterio ${ }^{150}$

En otras, los familiares se hacían con él por la fuerza y procedían a su sepelio en sagrado de forma ilegal.

Al qual Pero Biurrun sen licencia et mandamiento del seynnor governador desenforcaron de la forca et lo enterraron en Sant Bertholomeo. Et sobre esto el dito seynnor governador li oviesse mandado por su carta que certificado do era soterrado lo desenterrasse et por razon que el logar era perigloso et de nuytes levo con ssi XXX hombres et seyos tacaynnos por sacarlo de la fuesa et levarlo a la forca. Et ubrio las puertas de Sant Bertholomeo do yazia el dito cuerpo et sezolo desenterrar et levaronlo a la forca. Et de mandamiento del seynnor governador a eyll feyto de boca por razon que fazia la noch escura levo seyes torchas por tal que publicament fuese enforcado la segunda vegada con XII sueldos dados a los seyes

\footnotetext{
${ }^{148}$ Esta medida fue confirmada por el rey Eduardo a mitades del siglo X. Véase G. MINOIS, History of Suicide , p. 36. Sin embargo, en la legislación hispánica no se encuentran referencias al suicidio hasta Las Partidas de Alfonso X. El Liber Iudicum (Fuero Juzgo, año 654) no considera este tema, sin duda, porque fue entendido como un asunto meramente eclesiástico. A. GUIANCE, Los discursos sobre la muerte, p. 363.

${ }^{149}$ «Orden a Lope García, alcalde de Navascués, de informarse sobre la persona de Lopeco, que se ahorcó estando enajenado, a fin de decidir si se debía o no enterrarlo en el cementerio, debiendo permanecer mientras tanto su cadáver en lugar sagrado en el tronco de un árbol, sin arrojarlo al aguạ». En F. IDOATE, Un registro de cancillería del siglo XIV (1958), doc. núm. 562 , Ariès tambien indica que existen ocasiones en que el cuerpo de un ahorcado es "enramado" permaneciendo colgado en los árboles del interior del cementerio debido a la condición de lugar de asilo de la cual gozaba. Vid. Philippe ARIËS, El hombre ante la muerte, Madrid, 1999, p. 61.

${ }^{150}$ Año 1366. F. VIDEGÁIN AGÓs, La muerte en Navarra, p. 138 y F. IDOATE, Un registro de cancillería del siglo XIV (1958), n. 635. Estos autores recogen otra noticias más, de carácter muy cancilleria del siglo XI 31 de octubre de, 1365 Carlos II, a instancias de sus deudos, accede a que sea enterrado en cementerio el cadáver de Gil Martiniz de Los Arcos, que había dado muerte a su mujer Ochanda, y que yacía hacía tiempo de bruces con horca y todo sobre el lodazal». F. VIDEGÁIN, La muerte en Navarra, p. 138 y Florencio IDOATE, Un registro de cancillería del siglo XIV. El cartulario de don Carlos II el Malo, "Príncipe de Viana", LXIX (1957), pp. 573-594, n. 112. En ambos çasos se trata de criminales, pero estas actuaciones podrían ser perfectamente aplicadas a determinados suicidas, como se ha visto en la nota anterior.
} 
tacaynnos et con $\mathrm{V}$ sueldos dados al qui lo enforco et con dos sueldos que costo una grant ssoga con que fue ligado muyt fuertemientres en manera que otra vegada non lo podiessen desenforcar et con XXII sueldos VI dineros que paguo por XV libras de cera que quemaron las torchas et a cada uno de los XXX hombres que aylla fueron VIII.en. dineros LXI sueldos VI dineros ${ }^{151}$.

Y en circunstancias más excepcionales, algunas leyes indican cómo debía ser inhumado el cadáver por otros métodos "civiles", en función del tipo de delito cometido. De tal modo, los suicidas en general, eran enterrados en las riberas arenosas de los ríos, mientras que los ahogados, a cinco pies del borde del agua. Un hombre que se arrojaba por una ventana era enterrado en una montaña o cerca de un camino, sujeto al suelo por tres grandes piedras que se colocaban sobre la cabeza, el vientre y los pies para asegurar que no molestase a los vivos ${ }^{152}$. En otras coyunturas eran frecuentes los enterramientos en los campos a las afueras de las ciudades, en fosas comunes y vertederos municipales, bajo las horcas, en los cruces de caminos, en las fronteras entre propiedades y en los límites jurisdiccionales, entre otros espacios ${ }^{153}$. Estas prácticas que se remotaban a los tiempos paganos se yuxtapusieron a la tradición cristiana ${ }^{154}$. Todas ellas se fueron aglutinando y cobrando forma en las diferentes normativas civiles que se codificaron en los diferentes territorios europeos, aunque fueron ampliamente condenadas por el Derecho canónico y civil, así como por un amplio número de juristas que las consideraban costumbres inhumanas ${ }^{155}$.

La muerte de un suicida estaba revestida de un carácter público. La intimidad no existía en ningún aspecto de la vida, menos en un acto como éste que suponía la deshonra de la familia y de la comunidad, por eso las leyes

\footnotetext{
${ }^{151} \mathrm{AGN}$, Comptos, Registros, 51, fols. 67 v.-68r., año 1344 y también en Reg. 53, fol. $24 \mathrm{r}$. y fol. 84 r., año 1345. A. MURRAY indica que, en los casos en que un cuerpo es enterrado ilegalmente en cementerio, es nuevamente desenterrado y vuelto a colgar, como ocurre en este ejemplo. Sin embargo, una vez que el cadáver comienza a mostrar signos de descomposición, se hace intocable, por lo cual, no puede ejercerse condena sobre él, de manera que se confecciona un muñeco que simula su cuerpo sobre el que se ejerce el ajusticiamiento. Esta práctica se data primordialmente en el siglo XIII, Véase The Curse on Self-Murder, p. 17, notas 26 y 27 pectivamente.

${ }^{152}$ Leyes de Zürich, J.-C. ScHMITT, Le suicide au Moyen Âge, p. 12. En las normativas de Rügen (1525-1531) se establece que quien se haya arrojado al río sea enterrado en las arenas de la ribera. Vid. A. MURRAY, The Curse on Self-Murder, p. 50, nota 171. Este autor también recoge en la página citada enterramientos de suicidas en marismas en las zonas costeras del norte recoge en la pagina citada en
de Europa y de Alemania.

${ }^{153}$ A. Murray, The Curse on Self-Murder, pp. 41-53. Así, en la Silesia del siglo XIII, cuando alguien se mata a sí mismo en una casa o en el campo, debe ser enterrado en un cruce de caminos, p. 46. 11-12.

${ }^{154}$ G. MinOIS, History of Suicide, pp. 35-37. J.-C. SCHMITT, Le suicide au Moyen Âge, pp.

${ }^{155}$ J.-C. SCHMITT, Le suicide au Moyen Âge, p. 17. La Iglesia, más que en la condena, centra sus esfuerzos a partir del siglo XIII en desarrollar un sistema de prevención apoyado en un fe teórica y práctica a un mismo tiempo. La parte teórica apunta a la contención de los vicios y la práctica de las vịtudes basándose para ello en la Psychomachia de Prudencio así como en las manifestaciones iconográficas. Como medida práctica, la confesión (anual desde el IV Concilio de Letrán de 1215), que permitirá al sacerdote bucear en las profundidades del alma del feligrés y ayudarlo a evitar o superar la desesperación y la lucha contra los vicios. Asimismo, G. MINOIS, History of Suicide, p. 34 y A. MURRAY, The Curse on Self-Murder, pp. 35 y 37.
} 
dotaban a su enterramiento de un sentido público. Las autoridades deseaban aplicar castigos ejemplares al mismo tiempo que creaban vehículos de prevención mediante diferentes normativas. Por tanto, establecieron un complejo ritual que diferenciaba cada clase de suicidio asociándolo a una determinada tipología de enterramiento. Interesaba, pues, que todas las personas que vieran sus tumbas identificaran rápidamente el tipo de crimen cometido, de ahí la diversidad de métodos de clasificación ${ }^{156}$.

No obstante, algunas personas procedían al ocultamiento del cadáver ante el temor de que el suicidio mancillase la honra de todos los parientes y amigos o de que les fuesen embargados los bienes familiares. Así sucedió en el caso de Sancho Ruiz de Larraona, que, habiendo hallado en su propia casa a su vecino ahorcado, se deshizo del mismo echándolo a un silo en el monte. Habiendo sido descubierto, se le impuso una pena de cien florines por encubrir la muerte ante las autoridades judiciales y mover el cuerpo del lugar donde se produjo el homicidio ${ }^{157}$, quizá porque impediría conocer con exactitud las pruebas que se necesitaban para proceder a las pesquisas de los oficiales de justicia.

Karlos por la gracia de Dios rey de Navarra conte dEvreux. A nostro bien amado et fiel procurador Garcia Martiniz de Leach. Salut. Como agora poco tiempo ha Martin Ferrandiz, vecino de Larrahona, desesperado de la gracia et missericordia de Dios, se ovies eill mesmo es enforcado et dapnado dentro en las casas de Sancho Ruyz de Larrahona, vezino del dicto logar. El quoal dicto Sancho Ruyz de su autoridat tomando officio de si mesmo sin clamar nin requerir a ningunno de meos officiales desenforco et solto al dicto Martin Ferrandiz et de fecho lo tomo et levo a los montes dentro et ailli lo echo et puso en un silo por la quoal cosa cosa al dicto Sancho Ruyz habra caydo et enconado en grandes penas enta nos et deviesemos fazer precedir contra eill segunt pertenescia. Empero por quoanto eill es hombre ynorant et non sabe el fuero nin la costumbre en tales cosas, venido a nos suplicando que eill non quere pliorar sobre esto con vos ante que se echa et sozmete de todo en todo a nostra merçe. Por esto nos rey sobredicto queriendo husar mas de missericordia que de rigor et por las causas et razones sobredictas que a esto nos mueven et en carta por honor et contemplacion de algunas qui por el nos han suplicado de nostra gracia principal autoridat et poder real al dicto Sancho Ruyz avemos remetido et prestado et por tenor de las presentes remetemos et quitamos a perpetuo toda pena criminal et civil que por la causa podria o deveria ser enconido enta nos pagando vos cient florines doro. Por que vos mandamos a vos et a quoalesquiere otros officiales a quin esto toque et pertenensce que al dicto Sancho Ruyz por causa et razon sobredicta tengades por quito et descargado sin le fazer demanda nin question alguna a eill nin a sus bienes herederos en ningun tiempo del mundo a perpetuo dar asi lo

\footnotetext{
${ }^{156}$ A. MURRAY, The Curse on Self-Murder, pp. 48-49.

${ }^{157}$ Véase asimismo la nota 79 referente a levantamiento de cadáveres de suicidas por autoridades judiciales.
} 
queremos et nos plaze. Datum en Pomplona XXVIII ${ }^{\circ}$ dia de aguosto. Anno Domini $\mathrm{M}^{\mathrm{O}} \mathrm{CCC}^{\mathrm{o}}$ tercio. Por el rey P. de Guirior ${ }^{158}$.

La propia justicia utilizó otros medios para deshacerse de los cuerpos de los suicidas, si bien su objetivo era muy diferente: evitar cualquier tipo de enterramiento. Por ello, se procedía a arrojarlos al río o al mar para ejercer, de este modo, una de las formas más ignominiosas de castigo. En una región muy localizada de Centroeuropa - que abarca los territorios del Norte de Suiza y ciudades como Estrasburgo, Frankfurt y Regensburg - fue práctica habitual, según lo indican diferentes tipos de documentos y la legislación regional, la introducción del cuerpo de un suicida en un barril cerrado que era lanzado al río. La cuba contenía, en algunos casos, una inscripción, a modo de advertencia, por la cual se ordenaba que fuera dejada navegar corriente abajo, porque ya se le había hecho justicia río arriba. Este uso parece datarse ya desde finales del siglo XIII pero fue en 1384 (Estatutos de Baden) cuando se redactó la primera normativa, permaneciendo activa esta costumbre hasta el siglo $\mathrm{XVI}^{159}$.

En los territorios hispánicos no se tienen noticias sobre estos usos. Aunque sí aparecen algunas referencias asociadas a otros delitos graves que, no obstante, pueden ponerse en relación con todo lo dicho. En primer lugar, las Partidas castellanas prescriben que, en los casos de parricidio, los autores de los crímenes deben ser arrojados a las aguas dentro de un saco junto con un gallo, un perro, una serpiente y un mono ${ }^{160}$, si bien no se conoce ningún caso de aplicación práctica de esta providencia. En el reino navarro sí que aparecen penas similares administradas en algunos homicidios de especial

\footnotetext{
${ }^{158}$ AGN, Comptos, Documentos, caj. 69, n. 39, II, 21 de Agosto de 1393.-Pamplona. Asimismo ocurre con Toda Ortiz, que se ahorcó, cuyo cadáver fue arrojado a un pozo por Johan Goicoa, de Larraona. Fue multado con 25 florines. (AGN, Comptos, Registros, 220, fol. 261 v., año 1393)

${ }^{159}$ J.-C. SCHMITT, Le suicide au Moyen Âge, p. 12. G. MinoIs, History of Suicide, p. 35. Y A. MURRAY, The Curse on Self-Murder, pp. 37-41.

${ }^{160}$ Partida $7^{\mathrm{a}}$, Tít. VIII, Ley 12. "Que pena meresce el padre que matare al fijo, o el fijo, que matare a su padre, o alguno de los otros parientes. Si el padre matare al fijo, o el fijo al padre, o el auuelo al nieto, o el nieto al auuelo, $\mathrm{o}$ a su visauuelo, o alguno dellos a el; $\mathrm{o}$ el hermano al hermano, o el tio a su sobrino o el sobrino al tio, o el marido, a su muger, o la muger a su marido, o el suegro o la suegra a su yerno o a su nuera o el yerno, o la nuera a su suegro, o a su suegra, o el padrastro, o la madrastra a su entenado, o el entenado al padrastro, o la madrastra, o el aforrado al que lo aforro. Qualquier dellos que mate a otro atuerto con armas, 0 con yeruas paladinamente, encubierto. mandaron los Emperadores e los sabios antiguos que este a tal que fizo esta enemiga que sea acotado publicamente ante todos, e desi que lo metan en un saco de cuero, e que encierrern con el un can, e un gallo, e una culebra, e un ximio, e despues que fuere en el saco que fuere en el saco con estas quatro bestias, cosan la boca del saco, e lancenlos en la mar, o en el rio que fuere mas acerca de aquel lugar do acaesciere. Otrosi dezimos que todos aquellos que diessen ayuda, o consejo porque alguno muriesse en alguna de las maneras que de suso diximos quer sea pariente del que assi muere, quier estraño, que deue auer aquella mesma pena que e matador». En G. LÓPEZ (glos.), Las Siete Partidas del Sabio Rey Don Alonso, vol. III. Mencionado por A. GUIANCE, Los discursos sobre la muerte, p. 369 y por L. VIVANCO, Death in fifteenth century Castile, p. 81 donde cita también, a propósíto del delito de parricidio, un texto posterior de Covarrubias que hace alusión a este mismo crimen y castigo. Véase también R. SERRA RUIZ, Honor, honra e injuria, p. 239.
} 
gravedad $^{161}$. Así lo recoge Daniel Sánchez Aguirreolea en su tesis doctoral y en la que aporta dos casos específicos datados en 1557 y en 1775. En el primero de ellos, se condenó en Pamplona a un hombre por el asesinato de su mujer a ser arrojado al río Arga desde el Puente de la Rochapea, tras haber sido arrastrado previamente por las calles de la ciudad y posteriormente ser introducido vivo en un barril junto con un gato, un perro y un gallo. Mientras que en el segundo María Josefa Aróstegui y Gaztambide, vecina de Vera de Bidasoa, fue condenada por el asesinato de su esposo a ser primero ahorcada y posteriomente arrojada al río en una cuba ${ }^{162}$.

Para la Navarra bajomedieval se tiene constancia documental de una práctica de cariz similar, en este caso aplicada a suicidios y delitos infames ${ }^{163}$. En unas ocasiones el cadáver del suicida era atado a una escalera y se dejaba flotar en el río ${ }^{164}$.

Item Domingo de Alfaro, vezino de Calchetas se enforco el mismo en su casa; costo una bestia que lo trayo a Tudela al rio dEbro, II sueldos; costo un escalera por que lo levasse Ebro ayuso, XVIII dineros; costaron las cuerdas pora ligarlo en lescallera, VI dineros ${ }^{165}$.

En otras, era amarrado a una tabla, que cumplía similar función a la escalera y al tonel ${ }^{166}$. Como consta en el ejemplo siguiente, por el cual se sometía a este castigo a Domingo de Epeloa.

Pro tabulis et cordis emptis ad preparandum et faciendum tabulatum ubi corpus Dominice de Epeloa, vicine dicte ville, que se suspendit, poneretur ut laberetur per aquam, de mandato gubernatoris, VIII solidos ${ }^{267}$.

\footnotetext{
${ }^{161}$ Para la época medieval pueden contarse algunos testimonios documentales de ahogamiento en el río de delincuentes y criminales. En 1307 Arguedas Elvira de Castro embarazada de cinco meses estuvo presa por los me ré en el río (AGN, Comptos, Registros, 11, fol. 5). En 1340 Micaela de Alli, que mató a un hombre en la sierra de Aralar, fue ahogada en Salinas (AGN, Comptos, Registros 43, fol. 226). Citado por Juan José MARTINENA RUIZ, Castillos reales de Navarra (siglos XIII al XVI), Pamplona, p. 565.

${ }^{162}$ Daniel SÁNCHEZ AGUIRREOLEA, Actitudes ante la criminalidad en la Navarra moderna: formas y represión del bandolersimo, Universidad de Navarra, Pamplona, 2004, pp. 272-273 (Tesis inédita). Quiero agradecer al autor de esta tesis sus facilidades para la consulta de su investigación.

${ }^{163} \mathrm{Se}$ han recogido un total de siete noticias en las que se hace referencia a que los cuerpos de los suicidas eran arrojados al agua y, más concretamente, a ríos.

${ }^{164}$ De escalera, sólo se habla explícitamente en un ejemplo documental.

${ }^{165} \mathrm{AGN}$, Comptos, Registros, 19, fol. 4 r., año 1319.

${ }^{166} \mathrm{De}$ tabla se habla explícitamente en dos ejemplos documentales hallados. En el resto, se habla de que los cuerpos fuesen arrojados al agua y no se dan más datos.

${ }^{167}$ Citado por F. SEGURA, Victimas y agresoras, p. 150, nota 56. (AGN, Comptos, Registros, 34 , fol. $50 \mathrm{v}$, año 1334). Assimismo, en el caso de algunos delincuentes, Véase F. IDOATE, Catálogo del AGN. Comptos. Registros, vol. LI, doc. num. 505: «...Enecuo de Redín, que había hurtado algunas ropas en Uroz; habiéndole perseguido cayó en "جa fuente cabo dicha villa y se ahogó. Se avisó al gobernador de lo ocurrido sin tocar el cadáver, ordenando éste que fuese puesto en una tabla et echado por lagoa ayuso, atándole con cuerdas». (AGN, Comptos, Registros, 51, fols. 99-104 - faltan folios 100 v. a 103r.-, año 1344).
} 
O como se puede apreciar igualmente, si bien de modo más detallado, en esta otra referencia documental por la cual se condenaba a esta pena a Lope de Olleta, cuyo cuerpo fue transportado en un ataúd y sobre unas mulas hasta Caparroso.

Item martes XXX dia del dicho mes dabril veno el mandamiento del seynnor rey que el dicho Lope dOilleta fuesse echado por el rio dAragon ajuso et costo vna tabla que de jus eill leuo XII sueldos.

Item costo una tabut en que fue leuado el cuerpo del dicto Lope dOilleta XL sueldos.

Item miercoles siguient $\mathrm{XX}^{\mathrm{o}}$ dia dabril fue leuado el cuerpo del dicho Lope dOilleta a la puent de Caparroso por lo echar agoa ajuso et fueron ailla $\mathrm{V}^{\mathbf{o}}$ de Bazta[n], Peral Periz, notario. Et braçeros Peral Peaso, Garcia Sanchiz de Caparroso, Peral dArtaxona, Johaniquo moço de Johan de Villagarcia et Garcia dEscudiello et por quoanto pudian malament a grant rogaria fueron los dichos so braçeros de que cada uno de loguero . $\mathrm{V}^{\mathrm{o}}$. reales de Castiella que valen IIII ${ }^{\circ}$ libras VIII sueldos X dineros.

Item fizieron de spensa los dichos $\mathrm{v}^{\mathbf{0}}$ de Baztan Peral Periz notario, et los dichos $v^{0}$ braçeros en Caparroso en pan, vino, carne et ceuada para dos caualgaduras, XVIII ${ }^{\circ}$ sueldos ${ }^{168}$.

Uno de estos testimonios es demoledor: tres ladrones que se habían suicidado en prisión, quemándose vivos, fueron condenados a este trágico final ${ }^{169}$. La descripción que se realiza sobre el estado de los cuerpos y cómo se procedió a sujetarlos a la tabla en que serían arrojados al río, es espeluznante:

...e con cuerdas tabla que costaron de eryrr por lagoa ayuso XLIII sueldos VI dineros. Item por despens de los dichos Salvador de Oncent e Yenego de Oncit su conpaynhero e Johan Martiniz de Mendaça coando fueron moertos a cabo de vn mes coando coando los sacaron de la preson que ohan tanto que ombre del mondo no sey podia acosstar a vn hombre qui en todo et qui los ligo en la carce $\mathrm{V}$ sueldos e a coatro ombres qui los tiraron e los sacaron con las coerdas a cada uno II sueldos XIII sueldos ${ }^{170}$.

Este tipo de puniciones entrañaban una mayor crueldad que las sanciones practicadas en los territorios centroeuropeos, pues mientras que el tonel escondía el cuerpo a la vista de aquellos que pudiesen otearlo desde las orillas, la tabla o la escalera garantizaban su flotamiento y su consecuente avistamiento corriente abajo, forzando a percibir el cadáver en sus diversas fases de descomposición. La identificación de este castigo con un suicidio era pues, plena y el efecto disuasor, en verdad, mucho más efectivo. Esta medida, sin duda, indica claramente la conciencia negativa que en el reino navarro se

\footnotetext{
${ }^{168}$ AGN, Comptos, Documentos, caj. 114, n. 8, fol. 30 r., 4 de Diciembre de 1412.

${ }^{169}$ Zabalo y Martinena recogen otro testimonio de un delincuente que se suicidó estando en prisión, y cuyo cuerpo fue arrastrado y ahorcado. Vid. J. J. MARTINENA, Castillos reales, p. 572 . Pamplona, 1973, p. 306.

${ }^{170} \mathrm{AGN}$, Comptos, Registros, 38-1, fol. $113 \mathrm{v}$., año 1337. Estos tres ladrones fueron echados al río Aragón en una zona aguas abajo del molino de Pastoriza (Sangüesa). (AGN, Comptos, Registros, 38-1, fol. 113v, ano 1337). Debo agradecer esta referencia a David Alegría Suescun.
} 
tenía sobre el acto suicida, considerado contra natura, y al que correspondía un castigo ejemplar. Como le ocurrió a Salomón, bufón del rey Carlos III, que se suicidó lanzándose por el talud del castillo de Olite, y cuyo cuerpo fue condenado a ser arrojado al río Aragón.

Primo a Bartholomeo de Baztan, notario, tenient logar de prevost por Johan des Mordes prevost dOlit el XXVII ${ }^{\circ}$ dia de março precedent les quoalles nos le avemos fecho dar et delivrar por las expensas de fazer levar el cuerpo da Salamon dicho Carrasco, judio servidor del ray, qui desesperado se echo en la taylada et nostro comandamiento fue levado a Caparrosso et echado por el rio dAragon en iuso, II florines que a XXIX pieça vallen LVIII sueldos ${ }^{171}$.

Cabe preguntarse si esta costumbre punitiva de la tabla o de la escalera fue únicamente navarra pero, ante la falta de testimonios que la muestren como pauta habitual en la península ibérica y la continuidad en siglos posteriores de la práctica del encubamiento en este mismo reino, como se ha mostrado, debe señalarse, cuando menos, su excepcionalidad y especular sobre su procedencia e indicar su implantación y perduración en las leyes navarras.

Por último, es muy importante aclarar que no todos aquellos que intentaban suicidarse lograban su propósito, sino que algunos de ellos sólo conseguían herirse. De tal manera, las tentativas de suicidio eran castigadas con fuertes sanciones pecuniarias para que sirviesen de escarmiento al resto de la comunidad. Los bienes de la víctima eran confiscados en un primer momento, como si se hubiese cometido el crimen, hasta que se obtenían resultados en la investigación de los hechos; momento en que eran devueltos si se pagaba la multa impuesta.

Anno a Nativitate Domini $\mathrm{M}^{\circ} \mathrm{CCCC}^{\circ} \mathrm{III}^{\circ}$, $\mathrm{XIII}^{\circ}$ dia de Septiembre en Olit en cort en juyzio alegado por el procurador fiscal qontra Johan Marin, vezino de Caparrosso diziendo que eill mesmo con un ganivet se avia comencado degoillar et se caro grant partida de los gargueros et fue en periglo de muert et por esto Johan Marin su fijo, firmando por el dicho su padre so cicura pena echo i sozmetio al dicho su padre a la merçe del sennior rey. Et por esto por la dicha cort fue condepnado el dicho Johan Marin en L florines dar et pagar aqueillos al dicho procurador para el sennior rey ata $\mathrm{X}$ dias. Et de toda la dicha acusacion dado por quito et mandado desenbargar sus bienes ${ }^{172}$.

${ }^{171}$ AGN, Comptos, Documentos, caj. 113, n. 38, II-1, fol. 1 r. Cit. F. VIDEGÁin, La muerte en Navarra, pp. 151-152, nota 161: «El 27 de marzo de 1414 un servidor del rey Carlos III, un pobre bufón judío, se arrojó a la "tayllada" del palacio de Olite. No sabía nadar. Su cuerpo cadáver fue mandado llevar por Bartolomé de Baztán, lugarteniente del preboste, a Caparroșo; y allí echado por el rio Aragon ayuso. El rey no dispensaba de la maldita suerte ni a sus propios servidores. En este caso Salomón, alias Carrasco».

${ }^{172}$ AGN, Comptos, Papeles Sueltos $2^{\text {a }}$ Serie, leg. 6, n. 4 XXVII, 13 de Septiembre de 1403 .Olite. Y también AGN, Comptos, Registros, 275, fol. 235 v., año 1403: «De Johan Maryn. vezino de Caparroso, por quanto eill mesmo, con un ganivet, se avia començado a degoillar et vezino de Caparroso, por quanto eill mesmo, con un ganivet, se avia començado a degoillar et se taillo partida del gorguero, et fue en periglo de muert por la dicha cort, fue condepnado dar
et pagar L florines paral seynnor rey et de todo lo al dado por quito como peresce por cedula notada por el dicho Nicolau XIII ${ }^{\circ}$ dia de Setiembre IIII.c.III ${ }^{\circ}$. Por esto aqui los dichos L florines a XXVIII' ${ }^{\circ}$ sueldos pieça valen LXX libras». 
Las normativas canónicas también recogieron esta cuestión y, al igual que las civiles, imponían fuertes penas a las víctimas, en este caso de carácter espiritual. Así, un concilio visigótico celebrado en Toledo en el año 693 ya establecía para estas personas su apartamiento de la comunidad de fieles durante dos meses ${ }^{173}$.

Sin duda alguna debe promulgarse una norma de los obispos, a fin de que poden con las austerísimas tijeras de la penitencia, los vicios inusitados, y corten por todos los medios con nuevas y rígidas normas, la úlcera que habiendo aparecido de repente en los miembros unidos, los corrompe y contagia. Porque se ha introducido la grave costumbre de la desesperación de algunos hombres, que cuando son castigados, con cualquier pena por alguna negligencia, o encarcelados para satisfacer con la penitencia, y purgar así su crimen, de tal modo les ataca la tentación de la desesperación, que prefieren ahorcarse o quitarse la vida con arma blanca u otros medios mortíferos, y si no es por algún cambio de circunstancias, el diablo ejecuta en ellos su propósito. Por lo tanto, deseando poner término a estos pésimos consejos y aplicar un conveniente remedio a tal enfermedad, decreta la sacratísima reunión de nuestra asamblea, que aquel que cayere en tales trampas, si por casualidad escapare a la muerte, será alejado por todos los medios de la comunidad de los católicos, y del Cuerpo y Sangre de Cristo durante dos meses, porque conviene que por las penas de la penitencia se vuelva a la primitiva esperanza y salvación, el que intentó entregar su alma al diablo por medio de la desesperación ${ }^{174}$.

Debe concluirse, por consiguiente, que los poderes medievales se preocuparon muy específicamente de que, tanto los suicidas como los supervivientes de un suicidio, fuesen castigados de forma modélica frente al resto de la sociedad.

Así, a los suicidas se les aplicaba una sucesión de penas muy bien definidas que guardaban gran similitud entre los diferentes territorios europeos. Abarcaban desde vejaciones físicas hasta puniciones materiales y espirituales, que les privaban, además, de sus bienes materiales y de los sacramentos cristianos. Como consecuencia de todo ello, perdían su posición tanto en el mundo de los vivos como en el mundo de los muertos, y pasaban a formar parte de una sociedad de pecadores indeterminada para la que no existía el perdón, ya que habían cometido el más grave de los crímenes, la renuncia a la vida, símbolo espiritual del amor del Creador ${ }^{175}$. Hubo, sin embargo, numerosos juristas civiles y canónicos que se opusieron a todos los tormentos y sanciones que se aplicaban, en los que primaba un afán más racional y purista que pretendía librar a estas prácticas de sus reminiscencias paganas. Opinaban que el mayor castigo residía exclusivamente en las manos

\footnotetext{
${ }^{173}$ Tomado de A. GuiAnCE, Los discursos sobre la muerte, p. 362.

${ }^{174}$ Concilio de Toledo XVI, año 693. IV, De los desesperados. Publ. José VIVES (ed.); Tomás MARÍN MARTÍNEZ; Gonzalo MARTÍNEZ DÍEZ (colaboradores), Concilios visigóticos e hispanoromanos, Madrid, 1963, p. 501.

${ }^{175}$ Así lo expresa San Agustín. En G. MinoIs, History of Suicide, p. 28.
} 
SUICIDIO Y MUERTE ACCIDENTAL EN LA NAVARRA BAJOMEDIEVAL

de Dios, por lo que todas estas acciones que se cometían contra ellos se revestían de un carácter ignominioso que no las justificaba ${ }^{176}$.

Los investigadores han concluído que la Iglesia, más que castigar, tendía a prevenir en la sociedad estos suicidios por medio de actos de contricción y penitencia cuyo objeto era persuadir a quienes deseaban su propia muerte y ayudar a quienes sufrían desesperación y tentaciones ${ }^{177}$. A los supervivientes, se les asignaba una sanción pecuniaria y espiritual -una elevada multa y la privación temporal de los sacramentos-que les impedía participar en la vida diaria de la comunidad, con su correspondiente exclusión social y religiosa. El pecador arrepentido, una vez perdonado, se reintegraba a la vida y a la comunidad de fieles sin mayores consecuencias.

Todo esto viene a sumarse a los datos que ofrecen las propias investigaciones y que indican la práctica de muchas de estas costumbres en Grecia y Roma, así como por algunos pueblos germanos y celtas siglos antes de la llegada del cristianismo. Y aunque la imagen del suicidio que esta religión transmitió durante toda la Edad Media y parte de la Edad Moderna fue muy negativa es conveniente revisar esta idea. Los diferentes autores indican que el sustrato anterior ya apuntaba una condena del suicidio por algunas sociedades precristianas, pese a lo cual la imagen que ha prevalecido ha sido la de la Roma clásica, donde el suicidio era considerado un acto noble, privilegiado, reservado a las clases altas.

Por contraposición la idea que ha predominado respecto a la etapa medieval es la de la asimilación de suicidio y suplicios del cadáver. Si bien es cierto que durante este período la Iglesia condenó las actitudes suicidas, es de destacar que se limitó a aplicar únicamente la privación de sepultura y de sacramentos, centrándose más bien en combatir las tentaciones diabólicas y la desesperación por medio de otros instrumentos más humanos como la confesión, la penitencia o la literatura de carácter moralizante. De tal modo, el empleo de los castigos físicos era principalmente ejercido por las autoridades civiles que potenciaron y ejercieron las penas de ajusticiamiento de los suicidas. Pero, sin embargo, no radicó en ellas una única responsabilidad, sino que estos usos habían sido practicados desde tiempos ancestrales. Así pues, era toda la comunidad, al completo, la que ejercía presión sobre los que ponían fin a sus vidas. Los matices, en este caso, son, pues, muy importantes. Si bien en los tiempos precristianos se buscaron fórmulas para castigar a los homicidas, a los suicidas se les aplicaron con singular dureza, pues el abandono voluntario de la comunidad de los vivos, se consideraba como un acto de traición a los supervivientes. Ante el temor de que los espíritus de los fallecidos en estas circunstancias tomasen forma para molestarlos, estos hombres idearon una serie de costumbres de escarnio y enterramiento en función del tipo de suicidio cometido, que estaban exentas del matiz religioso cristiano. La llegada del cristianismo ocasionó la yuxtaposición de las mismas a los rituales religiosos, lo que provocó numerosos problemas doctrinales que

\footnotetext{
${ }^{176}$ A. MurRay, The Curse on Self-Murder, pp. 32-35.

${ }^{177}$ J.-C. SCHMIT, Le suicide au Moyen Âge, pp. 12-17.
} 
la Iglesia trató de solventar con una práctica más humanitaria que apuntaba al alma de los hombres. De igual manera, los castigos corporales a los suicidas perdían el valor por sí mismos, pues negaban el poder supremo de Dios para juzgar los crímenes de los seres humanos. Por todo ello, canonistas y juristas se opusieron a estas prácticas, que consideraban injustificadas e inhumanas, proponiendo métodos de actuación más racionales y basados en la aplicación de la doctrina de la Iglesia.

Debe recalcarse la existencia de diferencias conceptuales sobre la cuestión del suicidio en los diferentes territorios. Ariel Guiance piensa que, en el caso de Castilla, fueron principalmente las jerarquías religiosas las encargadas de regular las cuestiones sobre la sepultura y los auxilios espirituales. Las autoridades civiles se desentiendieron de estas materias y más bien legislaron otros aspectos del suicidio, como la aplicación de la justicia física (determinación de responsabilidad de la víctima en su muerte, castigos corporales, confiscación de bienes).

Para Navarra, no puede atribuirse este modelo. La ausencia de condena del suicidio en los sínodos, en las ordenanzas municipales o en los estatutos de cofradías, hace pensar que este asunto fue controlado directamente por la autoridad real. Así, el monarca, a través del Fuero General y de los fueros locales que concedió a diferentes localidades del reino, establecía los castigos que se debían aplicar a los suicidas. Desde las sanciones físicas (ajusticiamiento del cadáver, confiscación de bienes, desembargo de propiedades, determinación de la culpabilidad o inocencia de la víctima) hasta su sepultura (enterramiento en sagrado o arrojamiento a ríos), todo estaba perfectamente controlado por el aparato administrativo, como se ha podido comprobar a través de numerosos textos documentales.

Todo esto viene a corroborar dos cuestiones. Por un lado, el grado de poder ejercido por el monarca en el reino, en todos los niveles, ya que toma decisiones de índole material, ligadas a sus poderes y la eficacia de la administración navarra al servicio del mismo. Por otro, llama profundamente la atención que el rey también controlara asuntos de índole religiosa, por lo que es muy posible que el suicidio fuese considerado como un acto de traición contra su persona, como ocurría en Inglaterra, por lo que la aplicación íntegra del castigo le correspondía en exclusividad. De tal manera, la Iglesia no intervendría de forma directa en esta cuestión, siendo mero testigo, quedando encargada de ratificar las decisiones tomadas por el monarca y de llevar a la práctica la asistencia espiritual a la víctima en el caso de que así le fuese requerido.

Finalmente, debe señalarse que la severidad de las penas impuestas a los suicidas (el castigo de la tabla o escalera resalta por su crudeza) indica claramente una concepción muy negativa del suicidio entre los navarros, como una ofensa al más grave nivel. Así pues, la desesperación a la que sucumbían estos hombres era considerada preferentemente como una concesión a las fuerzas del mal, y una flaqueza moral por su debilidad en la lucha contra los vicios. Asimismo suponía una total rebelión contra el orden natural ya que atacaba en primer lugar la autoridad de Dios, creador de la vida, del monarca, su representante y máxima autoridad terrenal, y contra la comunidad, de la 
que la víctima formaba parte. Por todo lo cual, el suicidio requería los más abominables castigos terrenales y espirituales como pecado nefando que era. Pero la rigurosidad de la justicia implicaba una investigación de las causas del crimen, por lo que si se determinaba la influencia de la locura en los actos del suicida, se fijaban una serie de atenuantes que aligeraban la gravedad del pecado cometido, quedando resarcido tanto en el plano material (devolución de propiedades, reinserción social de los familiares en la comunidad) como en el espiritual (funerales cristianos y sepultura en suelo sagrado, aunque con menor número de ceremonias religiosas de lo habitual).

A pesar de que todas las medidas que se tomaban para evitar el suicidio - algunas de las físicas realmente truculentas y las espirituales, con su condena eterna, angustiosas para un hombre medieval, cristiano, que basa su vida en la esperanza de resurrección- debían ejercer un efecto desalentador, se siguieron cometiendo suicidios regularmente. Por ello, las causas últimas del suicidio, muy íntimas, escapan al investigador. El hambre y la pobreza que afectaban a una gran mayoría de la población, las epidemias y enfermedades que sufrían hombres y animales, las plagas que arrasaban los cultivos, las alteraciones del medio natural, los problemas de convivencia humana, todos ellos y muchos más fueron razones decisivas que empujaban a hombres y mujeres a poner fin a su vida. Pero no deja de ser llamativo pensar cómo y por qué una persona de esta época puede elegir esta vía de escape cuando supone para ella una vida peor que la que dejaba en la tierra, y el sufrimiento de horrendos castigos en el Infierno que formarían parte de su condenación eterna. Así pues, cabe preguntarse si, cuando recurrían al suicidio, realmente actuaban por desesperación o locura buscando una salida a un sufrimiento insoportable o si bien buscaban una última esperanza y la benevolencia divina en el más allá. Su actuación no fue en ningún caso comprendida por sus coetáneos, porque para una mente medieval, no había ninguna salida viable para semejante actuación: neminem uelut desiderio uitae melior post mortem uita non suscipit ${ }^{178}$.

Fecha de recepción del artículo: febrero 2006.

Fecha de aceptación y versión final: marzo 2007.

\footnotetext{
178 «Nadie sabe lo que pasa en el hombre, sino el espíritu del hombre que está en él. Esto decimos, esto afirmamos, esto de todos modos aprobamos: que nadie debe darse la muerte de su propio albedrío, no sea que, por huir de molestias temporales, vaya a dar en las eternas. Ninguno aquel a quien no afectaba ni manchaba el ajeno. Ninguno, por pecados pasados, por los propiles aquel a quien no afectaba ni manchaba el ajeno. Ninguno, por pecados pasados, por los cuales mas necesaria nos es esta vida para que los podamos subsanar mediante la penitencia. Ninguno, como por deseo de vida mejor, que tras la muerte se espera, porque a los culpables de su muerte, despues de la muerte no los acoge mejor vida». Vid. SAN AGUSTín, La ciudad de Dios (Libros I-II); Lorenzo RIBER (trad.), Barcelona, 1953, vol. I, libro I, cap. 26-4, p. 53. Cfr. J.-C SCHMITT, Le suicide au Moyen Age, pp. 18-19. Dante Alighieri situa a los suicidas (violento contra sí mismos) en el séptimo círculo del Infierno, como un bosque de árboles animados y gimientes asediados por las arpías, que arrancan sus ramas y hojas a mordiscos y picotazos, con gran dolor para ellos. Véase Dante ALIGHIERI, La Divina Comedia; Abilio ECHEVERRÍA (trad.) Carlos ALVAR (prólogo), Madrid, 1995, canto XIII, p. 78.
} 